\title{
Effects of Foliar Treatment with a Trichoderma Plant Biostimulant Consortium on Passiflora caerulea $\mathrm{L}$. Yield and Quality
}

Tatiana Eugenia Şesan ${ }^{1,2}$, Anca Olguța Oancea ${ }^{3}$, Laura Mihaela Ştefan ${ }^{3}$, Vasile Sorin Mănoiu ${ }^{3}$, Marius Ghiurea ${ }^{2}{ }^{-}$, Iuliana Răut ${ }^{2}$, Diana Constantinescu-Aruxandei ${ }^{2}$, Agnes Toma ${ }^{3}$, Simona Savin ${ }^{3}$, Adriana Florina Bira ${ }^{4}$, Cristian Mihai Pomohaci ${ }^{5}$ and Florin Oancea ${ }^{2,6, *}$ (D)

1 Department of Botany and Microbiology, Faculty of Biology, University of Bucharest, Aleea Portocalilor nr. 1-3, sector 6, 060101 Bucharest, Romania; tatianasesan@yahoo.com

2 Departments of Biotechnology and Bioresources, National Research \& Development Institute for Chemistry and Petrochemistry-ICECHIM, Splaiul Independenței nr. 202, sector 6, 060021 Bucharest, Romania; ghiurea@gmail.com (M.G.); iulia_rt@yahoo.com (I.R.); diana.c.aruxandei@gmail.com (D.C.-A.)

3 Department of Cellular and Molecular Biology, National Research \& Development Institute for Biological Sciences, Splaiul Independenței 296, sector 6, 060031 Bucharest, Romania; oancea.anca@gmail.com (A.-O.O.); LauraMihaelaStefan@yahoo.com (L.M.S..); spagiricus@yahoo.com (V.S.M.); agnes12ro@yahoo.com.au (A.T.); simonatulea@yahoo.com (S.S.)

4 Department of Research \& Development, Hofigal SA, Intrarea Serelor, Nr. 2, Sector 4, 042124 Bucharest, Romania; adrianaflorinabira@yahoo.com

5 Department of Mathematics, Physics and Land Measurements, Faculty of Land Reclamation and Environmental Engineering, University of Agronomical Sciences and Veterinary Medicine, Bulevardul Mărăști 59, sector 1, 011464 Bucharest, Romania; informatico@gmail.com

6 Biotechnologies Department, Faculty of Biotechnologies, University of Agronomical Sciences and Veterinary Medicine, Bulevardul Mărăști 59, sector 1, 011464 Bucharest, Romania

* Correspondence: Florin.Oancea@icechim.ro; Tel.: +40-21-316-3071

Received: 29 December 2019; Accepted: 13 January 2020; Published: 16 January 2020

Abstract: The influence of spore concentration on the ability of a Trichoderma consortium to colonize the Passiflora caerulea phyllosphere was evaluated by determining the effects of foliar treatments with two spore concentrations, in two repeated treatments, on the morphological, physiological, and ultrastructural characteristics, and on the yield and quality of $P$. caerulea. The studied crop quality features were related to its nutraceutical use: the accumulation of polyphenols and flavonoids, antioxidant activity, and effects on mouse fibroblast L929 cells. The Trichoderma consortium consisted of two strains, T. asperellum T36b and T. harzianum Td50b, and the concentrations used were $10^{6}$ colony forming units $(\mathrm{cfu}) / \mathrm{mL}$ and $10^{8} \mathrm{cfu} / \mathrm{mL}$. As a reference treatment, a commercial product that was based on herbs and algal extracts was used. As compared to the negative control, the treatment with the Trichoderma consortium at $10^{8} \mathrm{cfu} / \mathrm{mL}$ concentration determines the accumulation of higher level of polyphenols and flavonoids and increased antioxidant activity. This enhancement of $P$. caerulea quality characteristics after treatment with the higher concentration of Trichoderma consortium was associated with larger leaves, increased number and size of chloroplasts, improved plant physiology characteristics, and an increased yield. The treatment with high concentration of Trichoderma consortium spores promotes phyllosphere colonization and benefits both crop yield and quality.

Keywords: phyllosphere colonization; spores concentration; leaf area; leaf ultrastructure; polyphenols and flavonoids; antioxidant activity; stomatal conductance; chlorophyll fluorescence; cells culture biocompatibility; crop yield and quality 


\section{Introduction}

Plant-beneficial fungi from the Hypocrea/Trichoderma genera are among the most widespread microorganisms used in agriculture [1]. Selected and highly active strains are applied as seed [2], soil [3], and foliar treatments [4], and they are largely used as bio/myco-fungicides [5,6], plant biostimulants [7], and biofertilizers [5,8]. The multifaceted actions of plant-beneficial Trichoderma strains are determined by several mechanisms, which are mainly related to antagonism against plant pathogens [9] or activation of plant defence [10]. Such multifunctional strains produce hydrolases with lytic effects on plant pathogens [11] and/or that release specific oligosaccharide elicitors (damage-associated molecular patterns; DAMPs) from plant cell walls [12]. Several strains produce hydrolases together with proteins from the cerato-platanin family, weakening fungal cell walls and acting as microbial elicitors (pathogen or microbial-associated molecular patterns; PAMP, or, respectively, MAMPs) [13,14], as well as secondary metabolites, including peptides and volatile compounds, acting against fungal pathogens [11], activating plant defence response to stress [15], and/or improving plant root system morphology and physiology [16-18].

The activation of plant defence following Trichoderma treatments not only reduces plant diseases. In tomatoes, the defence barriers against both chewing herbivore insects (Spodoptera littoralis) and piercing-sucking aphids (Macrosiphum euphorbiae) were activated after Trichoderma atroviride P1 colonization [19]. Trichoderma application increased the plant tolerance to abiotic stress, such as drought [20], salinity stress [21], low temperatures [22], and recalcitrant pollutants [23]. The application of Trichoderma strains increases plant photosynthetic ability, up-regulating both light harvesting components and Calvin cycle (dark reaction) components [24]. Trichoderma and its secondary metabolites also enhance the uptake and use efficiency of macronutrients, such as nitrogen $[3,16]$ or phosphorus [25,26], and oligo/micro-nutrients, such as iron [8,27,28] or zinc [29].

In addition to higher yield, the treatment with plant-beneficial Trichoderma strains also contributes to enhanced nutritional quality [30]. This is because the activation of the plant defence response by Trichoderma strains is associated with higher accumulation of plant secondary metabolites, which are involved in plant defence against biotic and abiotic stress [31]. Such secondary metabolites are considered to be important phytonutrients for humans, with a significant function in maintaining human health [32]. Illustrative examples are artemisin, which accumulates in larger quantities in Artemisia annua following Trichoderma treatment [33], and bioactive compounds, including lycopene, which is higher in tomatoe fruits that are produced from Trichoderma-treated plants [34]. Treatment with Trichoderma strains, especially with those selected for their plant defence-triggering effects, was demonstrated to increase the polyphenolic content of various plants-grape [35], artichoke [36], and tomatoes [20]. Flavonoids and polyphenols were shown to increase the edible parts of onions [37] and cucumbers [38] after treatment with Trichoderma strains.

Plants from the Passiflora genus, which are commonly named passion fruits/passion flowers, are well-known for their effects on human health and wellbeing. The edible parts are considered to be nutraceutical/functional food [39]. The aerial parts of Passiflora plants are used as infusions, extracts, or tinctures due to their various effects: anti-depressive/anti-anxiolytic [40,41]; sedative/anti-sleep disorders [42]; anti-spasmolytic [43]; anti-asthma/anti-respiratory disorders [44]; anti-diabetic/hypolipidemic [45]; anti-hypertensive [46]; and, anti-addictive [47,48]. These effects have been related to the bioactive polyphenols and flavonoids [49,50] and their antioxidant [51-53], antimicrobial [52], prebiotic [51], and anti-inflammatory and analgesic [54-56] activities. To date, strains from Trichoderma genera were applied to Passiflora plants as bio/myco-fungicides for the treatment of fungal diseases $[57,58]$ or as biofertilizer to promote root growth and root function related to mineral nutrient uptake [59]. There are no studies regarding the influence of foliar treatments with Trichoderma strains on the accumulation of bioactive compounds in the aerial parts of the passion plants (largely used for nutraceutical purposes).

In this study, we determined the effects of foliar treatments with a Trichoderma consortium on the yield and quality of blue passion flowers. Such effects, which are specific for microbial plant 
biostimulants, are determined by the ability of the applied beneficial microorganisms to colonize the specific plant microbiocenosis, e.g., in the rhizosphere or phyllosphere, in competition with already existing microbes [60]. One strategy to promote inoculated Trichoderma capacity to colonize the plant microbiocenosis is that of repeated applications of the active strains, e.g., the highly effective T. harzianum strain T22 (ATCC ${ }^{\circledR} 20847^{\mathrm{TM}}$ ) was applied 10 times every two weeks at a density of $10^{8}$ spores per liter to Vitis vinifera cv. Sangioves to induce the accumulation of polyphenols in grapes [26]. Such strategy, despite its success, is difficult to scale-up due to the costs involved by the application of 10 treatments, even in the case of profitable horticultural crops.

The main aim of our study was to test another strategy, easier to scale-up, for the phyllosphere colonization with the applied beneficial microorganisms-a higher concentration of a Trichoderma consortium, containing a larger amount of chlamydospores [61], spores more resistant to adverse conditions in comparison to dried mycelia, and conidiospores, being applied in a lower number of treatments. The hypothesis was that the more resistant spores, from two compatible strains, will last longer in the (rather) hostile (for fungi) leaf habitat, having more chances for successful phyllosphere colonization. We tested two levels of spore concentration, $10^{6}$ and $10^{8} \mathrm{spore} / \mathrm{mL}$, applied as two treatments, and we determined the effects of the treatments on the yield and quality of Passiflora caerulea - polyphenol and flavonoid accumulation and antioxidant activity of leaves. Morpho-physiological determinations (leaf development and ultrastructure, leaf chlorophyll fluorescence, and stomatal conductance) were performed to demonstrate the colonization of the phyllosphere with the Trichoderma consortium and substantiate the effects on P. caerulea yield and quality.

\section{Materials and Methods}

\subsection{Biological Material}

Passiflora caerulea plants (blue passion flower) were grown in the Hofigal experimental field located south of Bucharest $\left(44^{\circ} 25^{\prime} 15^{\prime \prime} \mathrm{N}, 26^{\circ} 1^{\prime} 34^{\prime \prime} \mathrm{E}\right.$, altitude $\left.84 \mathrm{~m}\right)$ on a reddish preluvosol. The average values of multi-annual temperature, wind speed, daily sunshine duration, and total precipitation for this experimental site are $11.5^{\circ} \mathrm{C}, 3.2 \mathrm{~m} \mathrm{~s}^{-1}, 6.8 \mathrm{~h}$, and $615 \mathrm{~mm}$, respectively. The respective average multi-annual monthly temperature and precipitation are as follows: April- $13.8^{\circ} \mathrm{C}$ and $78.7 \mathrm{~mm}$; May- $16.1{ }^{\circ} \mathrm{C}$ and $84.2 \mathrm{~mm}$; June $-25.7^{\circ} \mathrm{C}$ and $53.6 \mathrm{~mm}$; July-27.5 ${ }^{\circ} \mathrm{C}$ and $42.7 \mathrm{~mm}$; August $-25.2^{\circ} \mathrm{C}$ and $68.7 \mathrm{~mm}$. During the experimental period, some differences compared to the multi-annual average were recorded. The average monthly temperatures were generally higher $\left(+1.1{ }^{\circ} \mathrm{C}\right.$ in April; $+0.7^{\circ} \mathrm{C}$ in May; $+2.3{ }^{\circ} \mathrm{C}$ in June, $-0.2{ }^{\circ} \mathrm{C}$ in July, $+0.4{ }^{\circ} \mathrm{C}$ in August $)$ and the average monthly precipitation was generally lower $(-11.4 \mathrm{~mm}$ in April; $-12.4 \mathrm{~mm}$ in May; $-9.6 \mathrm{~mm}$ in June; $+3.2 \mathrm{~mm}$ in July; $-4.8 \mathrm{~mm}$ in August) than the multi-annual average. The experimental field was irrigated up to $80 \%$ field capacity during the whole vegetation period of Passiflora caerulea plants. For this study, a consortium formed of two strains from the INCDCP-ICECHIM collection, T. asperellum T36 NCAIM F 001434 and T. harzianum, Td50b, NCAIM F001412 was used as the microbial plant biostimulant. Both of the strains are multifunctional plant biostimulant strains. Both strains produce bioactive volatile compounds, including 6-pentyl-2H-pyran-2-one-6-PP [62,63]; both are antagonist against major plant pathogens [63,64], protect and stimulate vegetable growth [65], accelerate the degradation of lignocellulose material, and promote development in early stages of the plants that are cultivated in high residue systems, i.e., mulch produced from winter cover crops [66,67]. This highly compatible consortium was grown in a medium promoting chlamydospore accumulation: $34.2 \mathrm{~g} / \mathrm{L}$ glucose, $0.37 \mathrm{~g} / \mathrm{L}$ ammonium sulphate, $0.8 \mathrm{~g} / \mathrm{L}$ yeast extract, $2.7 \mathrm{~g} / \mathrm{L}$ soymeal, $1.2 \mathrm{~g} / \mathrm{L} \mathrm{K}_{2} \mathrm{HPO}_{4}$, and $1.7 \mathrm{~g} / \mathrm{L} \mathrm{KH}_{2} \mathrm{PO}_{4}$ [68] at $25{ }^{\circ} \mathrm{C}$, with light $(16 \mathrm{~h}$ day $/ 8 \mathrm{~h}$ night) for two weeks. The mycelium was homogenized with the culture medium by vigorous shaking, and the resulting suspension was aseptically poured through a 100-mesh cotton tissue. The spores were collected in a sterile bottle and then concentrated by centrifugation [69]. The concentration of the Trichoderma consortium propagules 
was normalized to $10^{6}$ and $10^{8} \mathrm{cfu} / \mathrm{mL}$ by microscopic counting of fungal spores on a hemocytometer according to a standardized protocol prior to the application as treatment of P. caerulea plants [70].

\subsection{Field Experiment}

The experiment included three different foliar treatments, which were compared with the control, as follows: C-control (no treatment with plant biostimulants; treated only with water, volume equivalent to $200 \mathrm{~L} / \mathrm{ha}$ ); $\mathrm{T}_{1}$ - foliar treatment with Trichoderma consortium suspension, $10^{6} \mathrm{cfu} / \mathrm{mL}$, with a normalized spraying volume equivalent to $200 \mathrm{~L} / \mathrm{h}$ a corresponding to a dose of $2 \times 10^{11} \mathrm{spores} / \mathrm{ha}$; $\mathrm{T}_{2}$-foliar treatment with Trichoderma consortium suspension, $10^{8} \mathrm{cfu} / \mathrm{mL}$, spraying volume $200 \mathrm{~L} / \mathrm{ha}$, equivalent to a dose of $2 \times 10^{13}$ spores/ha; and, $\mathrm{T}_{3}$-foliar treatment with a reference product (Amalgerol, Hechenbichler, Innsbruck, Austria) that contains plant extracts, essential oils, and fatty acids in an oil/water emulsion and extract of the seaweed Ascophyllum nodosum applied at $1.2 \%$ concentration at a normalized spraying volume of $250 \mathrm{~L} /$ ha, corresponding to a dose of $3 \mathrm{~L} /$ ha. The reference product was selected because it was demonstrated to significantly enhance the accumulation of polyphenols [71] and contains both elicitors (from herbs and seaweed extract) and volatiles (essential oils). The spore concentrations of the Trichoderma consortium were selected in accordance with the demonstrated effects on P. caerulea morphology [72]. The experiment was randomized in a Latin square design and each treatment had four repetitions. Each experimental repetition included 50 Passiflora plants. The two treatments were applied using an SG20 backpack sprayer (Stihl AG, Waiblingen, Germany) at the beginning of June (leaf development and flower primordium formation) and at the beginning of July (flower development). The applied pressure of the back-up sprayer was set to $275 \mathrm{kPa}$. A nozzle with a flat jet and low drift (TeeJett ${ }^{\circledR}$ flat-fan TT11002 model, Spraying Systems, Wheaton, IL, US) was used.

\subsection{Determination of Morphological and Physiological Characteristics of P. caerulea Plants}

The $P$. caerulea plants were monitored during the whole experiment. Their morpho-physiological parameters were measured one day before the application of the first treatment, 7 days after the application of the first treatment and at the end of the experiment-at the beginning of August, 60 days after the application of the first treatment. P. caerulea leaves were sampled for biochemical analysis of bioactive compounds and for alternative tests on cell cultures on the same dates when the morphological and physiological characteristics were assayed. At the end of the experiment, the yield level was evaluated as the marketable biomass of aerial parts for each plot/repetition (15 plants harvested per repetition; plants were not previously sampled for aerial parts). The marketable biomass of $P$. caerulea represents $50 \%$ of the aerial parts of the nutraceutical plant, which can be harvested without compromising any further development of this perennial plant and it is marketable to produce infusions, extracts, or tinctures.

10 healthy leaves per repetition were randomly collected (in total, 40 leaves per experimental treatment) on each sampling date for the estimation of the average leaf area (LA). The leaf area $\left(\mathrm{cm}^{2}\right)$ was evaluated by two different methods, a classic one, using calculation and interpolation on squared paper, and an image analysis method, as already described [73]. Briefly, for the classic method, drawings of scanned fresh leaves on an A4 sheet of paper divided into squares of $5 \mathrm{~mm}$ were made. For the determination of the leaf surface by image analysis, the morphometric methods that were based on multiscale Minkowski fractal dimension [74] and Quick Photo Micro 2.3 software (Promicra, Prague, Czech Republic) were used. The classical method for calculation of the leaf area involves the use of the length (L) and width (w) of the leaf, according to the following equation [75]:

$$
\mathrm{LA}=\mathrm{L} \times \mathrm{w} \times \mathrm{k} .
$$

In Equation (1), $\mathrm{k}$ is a coefficient specific for each plant species/variety and plant development stage. The length, width, and area of each of the scanned fresh leaves on squared paper were measured. The resulting k coefficient was calculated and statistically analyzed. 
The measurement of chlorophyll fluorescence of Passiflora plants was undertaken with a PAM fluorometer (Walz PAM 2500, Effertlich, Germany), according to the manufacturer's instruction. The determinations were done on 10 leaves that were randomly chosen per repetition (selected from representative upper leaves of healthy plants from each repetition). Before starting the measurement, the leaves were pre-darkened for $30 \mathrm{~min}$. by using a brown paper bag, after which saturation light pulses were applied. The maximum photosystem II (PSII) quantum efficiency, i.e., the ratio between $\mathrm{F}_{\mathrm{v}}$, variable fluorescence, and $\mathrm{F}_{\mathrm{m}}$, the maximum fluorescent yield in the dark-adapted state, was determined. The stomatal conductance $\left(\mathrm{nmol} \mathrm{m}^{-2} \mathrm{~s}^{-1}\right)$ of the $P$. caerulea leaves was measured with a Delta T AP4 porometer (Delta-T Devices, Burwell, UK) while using the same leaves on which the chlorophyll fluorescence was measured. Each determination was repeated three times.

\subsection{Ultrastructural and Morphological Analyses}

A Philips EM 208 S electron microscope (Philips Electron Optics, Amsterdam, Netherland) equipped with a Veleta video camera and imaging software iTEM (Olympus Soft Imaging Solutions, Münster, Germany) was used to investigate the ultrastructure of $P$. caerulea leaves. The samples were submitted to a 2-h plant-specific fixation process while using $1.5 \%$ paraformaldehyde, $1 \mathrm{M} \mathrm{Na}_{3} \mathrm{PO}_{4}$, and $3 \%$ glutaraldehyde. The fixation step was followed by rinsing with $0.5 \mathrm{M} \mathrm{Na}_{3} \mathrm{PO}_{4}$ (three times at $4{ }^{\circ} \mathrm{C}$ ). For the post-fixation step, the sample was transferred to the dark for $1 \mathrm{~h}$ in a solution of $1 \% \mathrm{OsO}_{4}$ and $0.5 \mathrm{M} \mathrm{Na}_{3} \mathrm{PO}_{4}$. After the post-fixation step, the samples were washed three times for $10 \mathrm{~min}$. in water at $4{ }^{\circ} \mathrm{C}$ and were then dehydrated by successive washing with ethanol for $10 \mathrm{~min}$. each: $12.5 \%$, $25 \%, 35 \%, 50 \%, 70 \%, 80 \%, 90 \%, 95 \%$, and $100 \%$. To replace the old solution and ethanol completely with an acetone-resin mixture, the dehydrated samples were incubated successively with acetone-resin (1:1) for $1 \mathrm{~h}$, acetone-resin (1:2) for $\frac{1}{2} \mathrm{~h}$, resin $100 \%$ for $1 \mathrm{~h}$, and then fresh resin $100 \%$ overnight. The leaf samples were placed in fresh resin $(100 \%)$ for $60 \mathrm{~h}$ at $50{ }^{\circ} \mathrm{C}$ to perform the polymerization step. The resin-embedded samples were cut with an ultramicrotome Leica UC6 (Leica Biosystem, Wetzlar, Germany) with a diamond knife, and the sections were placed on copper grids of 200 mesh that were covered with a formvar pellicle. The samples were stained for $7 \mathrm{~min}$. with $5 \%$ uranyl acetate in absolute methanol to increase the contrast. Subsequently, the samples were washed in distilled water and then re-stained for another $7 \mathrm{~min}$., with a solution of lead nitrate $4.4 \%$ and $0.2 \mathrm{M}$ trisodium citrate monohydrate in distilled water (with $1 \% \mathrm{NaOH}$ to clarify the solution). All of the reagents were of electron microscopy grade, supplied by Sigma-Aldrich (Sigma, Merck Group, Darmastad, Germany).

\subsection{Determination of Chloroplast Number and Their Surface in the Spongy Parenchyma}

The ultrathin sections of the leaves from control and plant biostimulant treatments were evaluated with transmission electron microscopy (TEM) to determine the changes in the ultrastructure of the spongy parenchyma and chloroplasts, as well as in the number of chloroplasts and their surface. These parameters were determined according to Zechman [76]. Briefly, 100 cells from the TEM images of spongy parenchyma from each replicate were visually inspected and the number of chloroplasts was determined by counting. The chloroplast surface was determined by image analysis. The perimeter of the chloroplast was manually tracked and the surface $\left(\mu \mathrm{m}^{2}\right)$ of the structure was determined while using calibrated ImageJ software 1.52P (http://rsbweb.nih.gov/ij/). The examination for chloroplast structure evaluation was undertaken for chloroplasts included into 10 different cells from four different samples per each replicate.

\subsection{Determination of Total Polyphenols and Flavonoids}

The sampled fresh plant material (leaves and sprouts with leaves) was dried at $50{ }^{\circ} \mathrm{C}$ for $24 \mathrm{~h}$, until 6-7\% final moisture content was achieved, and then ground in a laboratory mill (Retsch SM2000 (Retsch $\mathrm{GmbH}$, Haan, Germany) fitted with a $1 \mathrm{~mm}$ sieve. The resulting ground plant material was macerated in ethanol (EtOH) solution in pure water, $70 \%(v / v)$ for 10 days. After 10 days, the macerate was filtered through a vacuum filter, and the resulting filtrate was stored at $4{ }^{\circ} \mathrm{C}$ in dark bottles. 
In the ethanol macerate, the total polyphenols were determined while using the Folin-Ciocâlteu method [77], with some modifications [78]: $750 \mu \mathrm{L}$ of Folin-Ciocâlteu reagent, $4 \mathrm{~mL}$ of $15 \% \mathrm{Na}_{2} \mathrm{CO}_{3}$, and distilled water were added to $150 \mu \mathrm{L}$ of sample to a final volume of $15 \mathrm{~mL}$. The absorbance at $\lambda=$ $756 \mathrm{~nm}$ was measured after $2 \mathrm{~h}$ incubation at room temperature. The total phenolic compounds were expressed as gallic acid (GA) equivalents based on a calibration curve that was constructed with known concentrations of gallic acid. The aluminum chloride colorimetric method was used for total flavonoids assay [79]: $0.5 \mathrm{~mL}$ of sample was mixed with $1.5 \mathrm{~mL}$ ethanol, $0.1 \mathrm{~mL}$ of $1 \mathrm{M}$ potassium acetate, $0.1 \mathrm{~mL}$ of $10 \%$ aluminum chloride, and $2.8 \mathrm{~mL}$ of distilled water; the absorbance at $\lambda=415 \mathrm{~nm}$ was measured after $30 \mathrm{~min}$. incubation at room temperature. The flavonoid content was expressed as quercetin $(\mathrm{Q})$ equivalents while using a calibration curve constructed with known concentrations of quercetin. All of the determinations were done in triplicate. All of the reagents used were analytical-grade reagents purchased from Sigma-Aldrich (Merck Group, Darmastad, Germany).

\subsection{Antioxidant Activity Assay}

The antioxidant activity was determined by two different assays: scavenging of DPPH (2,2-diphenyl-1-picryl-hydrazyl-hydrate) free radicals and TEAC (Trolox equivalent antioxidant capacity). The hydroalcoholic macerate of $P$. caerulea aerial parts was evaporated while using a Rotavapor $^{\circledR}$ R-300 (Büchi, Flawil, Switzerland), and the exact quantities were re-solubilized while using the recommended absolute alcohols. All of the assays were performed in triplicate. All of the reagents used were analytical-grade reagents purchased from Sigma-Aldrich (Merck Group).

\subsubsection{DPPH Scavenging Activity Assay}

The DPPH scavenging activity was measured while using the method that was described by Huang et al. [51], with slight modifications: $150 \mu \mathrm{L}$ DPPH methanolic solution $(0.25 \mathrm{mM})$ was vigorously mixed with $15 \mu \mathrm{L}$ of sample (resolubilized in methanol) and $90 \mu \mathrm{L}$ of $0.1 \mathrm{M}$ Tris- $\mathrm{HCl}$ buffer. The resulting mixture was incubated at $37^{\circ} \mathrm{C}$ for $30 \mathrm{~min}$. in the dark. Butylated hydroxytoluene (BHT) was used as a positive control. The sample absorbance $\left(\mathrm{A}_{\text {sample }}\right)$ was read using a microplate reader (Sunrise, Tecan, Männedorf, Switzerland) at $\lambda=520 \mathrm{~nm}$ against a blank with methanol ( $\left.\mathrm{A}_{\text {blank }}\right)$. DPPH inhibition (\%) was calculated using the following equation:

$$
\% \text { Inhibition }=\left(1-\mathrm{A}_{\text {sample }} / \mathrm{A}_{\text {blank }}\right) * 100 .
$$

\subsubsection{Antioxidant Capacity (TEAC) Assay}

The antioxidant capacity (TEAC) was measured using the method of Re et al. [54], with slight modifications. The ABTS [(2,2'-azino-bis(3-ethylbenzothiazoline-6-sulphonic acid)] radical was generated by reacting a $7 \mathrm{mM} 2,2^{\prime}$-azino-bis (3-ethyl-benzothiazoline-6-sulfonic acid) diammonium salt (ABTS) solution with a $2.45 \mathrm{mM}$ potassium persulfate solution $(1: 1, v / v)$. The mixture was incubated in the dark at room temperature for $16 \mathrm{~h}$. The initial absorbance of the ABTS radical solution was equilibrated to a value of $0.7 \pm 0.02$ at $\lambda=734 \mathrm{~nm}$. Next, $0.1 \mathrm{~mL}$ test sample was mixed with $1 \mathrm{~mL}$ of the ABTS radical solution and incubated for $6 \mathrm{~min}$. After incubation, the absorbance was measured at $\lambda=734 \mathrm{~nm}$. A calibration curve of Trolox $(0-250 \mu \mathrm{M})$ was used to convert the absorbance into the equivalent activity of Trolox per $\mathrm{mL}$ sample $(\mu \mathrm{g}$ Trolox $/ \mathrm{mL})$.

\subsection{Cell Culture Biocompatibility}

The in vitro biocompatibility tests were done on dried macerate (the hydroalcoholic extracts, vacuum dried, on a Rotavapor ${ }^{\circledR}$ R-300, Büchi) that was resuspended into phosphate saline buffer (PBS). The resulting PBS extracts of the P. caerulea leaves were sterilized by filtration on $0.22 \mu \mathrm{m}$ Millipore filters (Merck Millipore, Darmstadt, Germany). The in vitro biocompatibility assays for Passiflora extract were done while using a stabilized line of mouse fibroblast L929 cells (ATCC, cell line, NCTC clone 929), which was provided by the European Collection of Cell Cultures (ECACC). The NCTC 
L-929 cells were cultivated in Eagle's MEM that was supplemented with 10\% fetal bovine serum (FBS) and antibiotics (100 mg/mL penicillin, $100 \mathrm{mg} / \mathrm{L}$ streptomycin, and $500 \mathrm{mg} / \mathrm{L}$ neomycin) at $37^{\circ} \mathrm{C}$ in a humidified incubator with $5 \% \mathrm{CO}_{2}$ (CelCulture ${ }^{\circledR}$ Incubator, Esco Medical, Barnsley, UK). The NCTC L-929 cells were seeded in 24-well plates at a cell density of $5 \times 10^{4}$ cells/mL for $24 \mathrm{~h}$ to allow for adherence and were then incubated in the presence of different dilutions $(1,10,50,100,150 \mu \mathrm{g} / \mathrm{mL})$ of $P$. caerulea extracts for 24 and $48 \mathrm{~h}$. The cell viability was determined using a colorimetric method, which was based on the ability of viable cells to incorporate a supravital dye, Neutral Red, NR [80]. Briefly, after the removal of the plant extract from the wells, a solution of the NR $(50 \mathrm{mg} / \mathrm{mL})$ was prepared in MEM that was supplemented with $10 \%$ fetal bovine serum. After an incubation period of $3 \mathrm{~h}$ at $37^{\circ} \mathrm{C}$ in $5 \% \mathrm{CO}_{2}$ atmosphere, the NR solution was removed, and an equal volume of fixative solution was added. The absorbance of the solution in the wells was read at $\lambda=540 \mathrm{~nm}$ while using a plate reader, i.e., Mithras LB 940 (Berthold Technologies, Bad Wildbad, Germany). The results were reported as percent viability relative to the control sample (cells incubated without the plant extract) considered $100 \%$ viable. The cell morphology was also evaluated. The NCTC L-929 cells, which were cultivated in the presence of various dilutions of plant extracts for $48 \mathrm{~h}$, were fixed in methanol and then stained with a Giemsa solution for $20 \mathrm{~min}$. Finally, the stained cells from different experimental treatments were examined under an optical microscope (Zeiss Observer, Carl Zeiss, Oberkochen, Germania), with a D1 $20 \times$ objective. The dry weight $\left(\mathrm{d}_{\mathrm{w}}\right)$ of the tested P. caerulea extracts was determined by using a thermobalance (Moisture Analyzer Balance, Radwag, Cracow, Poland). The presented data are the average of three determinations. All of the reagents were suitable for cell culture and purchased from the Sigma-Merck Group.

\subsection{Statistical Analysis}

The data were statistically analyzed by analysis of variance (ANOVA) while using the SPSS 21 software package (IBM, Armonk, NY, USA). The data were analyzed in evolution, deducting the initial data from the treatment data before the application of the treatment. A least significant difference (LSD) test was used to separate the treatment means within each measured parameter at a significance level of $p<0.05$. Coefficient $k$, from Equation (1), was statistically analyzed by the $\chi^{2}$ test (chi test).

\section{Results}

\subsection{Effects on Morphological and Physiological Characteristics}

The effects of treatment with the Trichoderma consortium depended on the applied concentration. At the higher concentration, the stimulation of the foliar development lasted up to 60 days after the first treatment. Initially, after the first seven days, the boosting effect of the Trichoderma application, on the foliar development when compared to the water treated control was statistically significant for both spore concentrations. In the case of the higher spore concentration, the stimulation of leaf development was higher than $23 \%$ for the length of the leaf and almost $45 \%$ for the width of the leaf, when compared to the water-treated control, as in Figure 1a,b. 


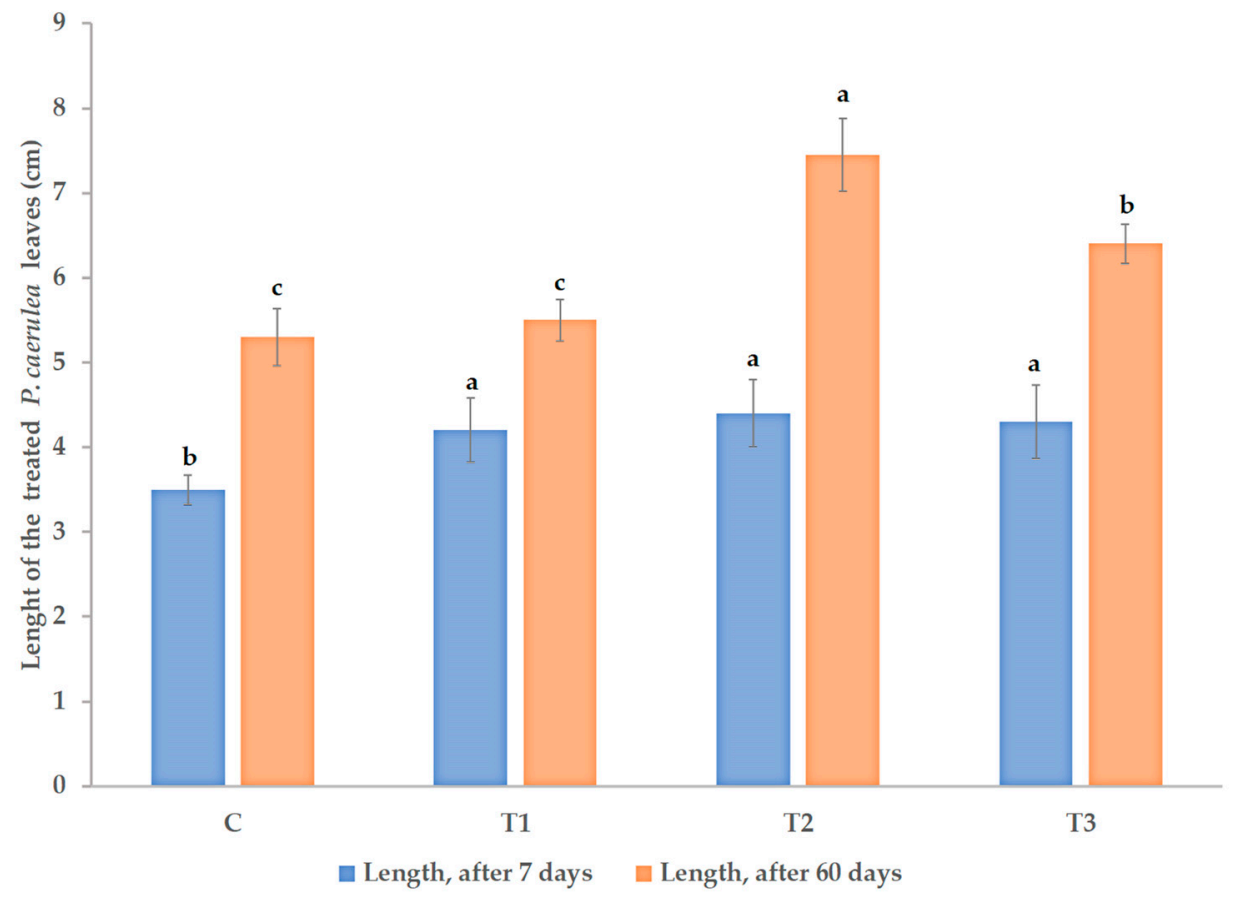

(a)



(b)

Figure 1. Cont. 




(c)

Figure 1. Effect of foliar treatment with plant biostimulants on the development of the leaves of $P$. caerulea plants after seven days from the first treatment and after 60 days from the first treatment: (a) effect on the leaf length (average of 10 leaves per replicate, four replicates per each treatment); (b) effect on the leaf width (average of 10 leaves per replicate, four replicates per each treatment); (c) effect on the average leaf area $\left(\mathrm{cm}^{2}\right.$, average of 10 leaves per replicate, four replicates per each treatment). $\mathrm{C}$ - control (no treatment with plant biostimulants, treated only with water); $\mathrm{T}_{1}$ - foliar treatment with Trichoderma consortium suspension, $10^{6} \mathrm{cfu} / \mathrm{mL}$, equiv. to $10^{11} \mathrm{spores} / \mathrm{ha} ; \mathrm{T}_{2}$-foliar treatment with Trichoderma consortium suspension, $10^{8} \mathrm{cfu} / \mathrm{mL}$, equiv. to $10^{13}$ spores $/$ ha; $\mathrm{T}_{3}$-foliar treatment with a reference product, consisting of plant extracts, essential oils, and fatty acids in an oil/water emulsion and extract of the seaweed Ascophyllum nodosum, equiv. to $3 \mathrm{~L} / \mathrm{ha}$. The values presented represent means \pm standard errors $(n=40$ plants). Columns that are labeled with different letters, compared between the different treatments $(C, T 1, T 2$, and T3) within each parameter and time period (after 7 days and, respectively, after 60 days) are significantly different at $p<0.05$.

The initial timepoint measurement (at seven days after the first treatment) was intended to determine the capacity of the lower concentration of Trichoderma consortium to colonize a small habitat. As mentioned, both concentrations had a significant stimulatory effect at seven days after the first treatment, when compared to water treated control. However, lower concentration of Trichoderma consortium determined lower stimulation of leaves development in length (around 20\% stimulation) and width (around 15\% stimulation). After 60 days, the leaf development was significantly stimulated only by the highest applied concentration of the Trichoderma consortium-more than $40 \%$ stimulation of leaf length and around $40 \%$ stimulation of the width. The reference plant biostimulant product, which was based on natural extracts, including volatile compounds (essential oils) and elicitors (from algae and plant extracts), had an intermediate influence under our experimental conditions, with a more pronounced stimulation effect after the second treatment when compared to the first week-Figure 1a,b. The development of leaves increases the dimensions of the habitat to be colonized by the applied microbial consortium. High leaf surface reduces the chances of the lower concentrated Trichoderma consortium spores to successfully colonize the enlarged habitat. 
These longer lasting effects of the Trichoderma consortium applied at $10^{8} \mathrm{cfu} / \mathrm{mL}$ concentration and, partially, of the reference product on leaf morphology also determined an increase in the leaf area, as in Figure 1c. The differences between the classical method of calculation of leaf area and the image analysis method were less than 5\% (Figure 1c). However, we used two different modes of calculation, because the classical method of leaf area calculation objectively evaluates the leaf irregularities. Within this formula, the coefficient $k$, which is specific to different plant species/varieties and plant development stages, is used. The average value that was calculated for coefficient $\mathrm{k}$ was 0.47 at the beginning of the experiment and 0.53 at the end of the experiment. The distribution of the coefficient $\mathrm{k}$, being statistically analyzed by the $\chi^{2}$ (Hi/chi squared) test, did not vary between treatments. These data are in agreement with the already published data [75], which established the specificity of coefficient $k$ for Passiflora spp., confirming the values that were calculated $(k=0.47-0.53)$ as being specific for a plant with normal development. The small differences between the two methods for calculation of the leaf area and the calculated $\mathrm{k}$ value, within the range of the published coefficient, demonstrate that the stimulation of $P$. caerulea by the Trichoderma consortium applied at the higher rate was not associated to the deviation of the leaves from their normal development.

Our determinations (Figure 2a) demonstrate a lower stomatal conductance for plant biostimulant-treated plants compared to the control. The Trichoderma treatments were previously shown to reduce stomatal aperture and improve the water use efficiency of the model plant Arabidopsis thaliana [81]. We observed a similar effect on P. caerulea under our experimental conditions-Figure 2a.

We estimated the maximum quantum efficiency of PSII by in situ determination of the chlorophyll fluorescence of the pre-darkened leaves. Our measurements on the Passiflora leaves do not demonstrate a statistically significant activation of the photosynthetic efficiency following plant biostimulant treatment, as in Figure 2b. Trichoderma plant biostimulants were reported to enhance the intensity of photosynthesis and to modulate chlorophyll fluorescence in Micro-Tom tomatoes [82]. Under our experimental conditions, with measurements done under high photosynthetic active radiations, we only noticed a tendency for an increased photosynthetic efficiency, which is at the limit of statistical significance of $p<0.05$.

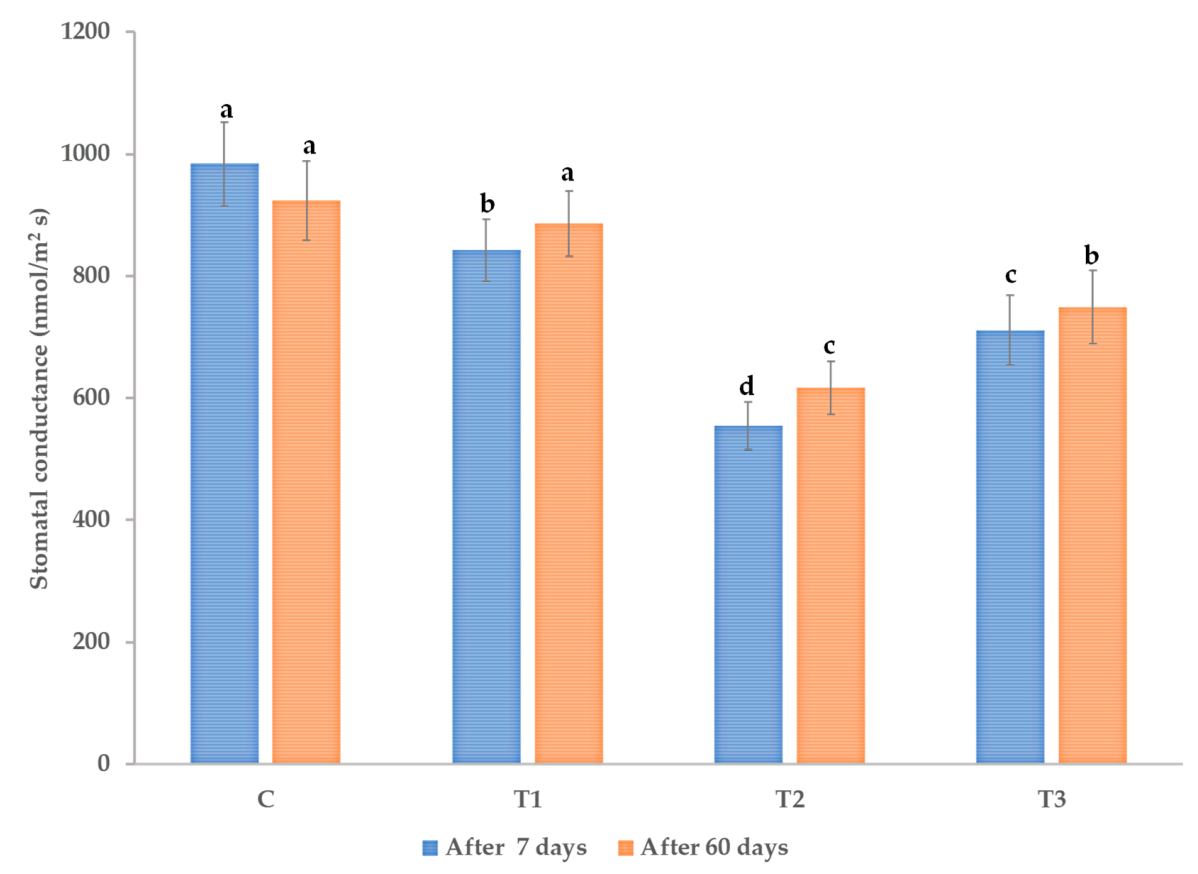

(a)

Figure 2. Cont. 


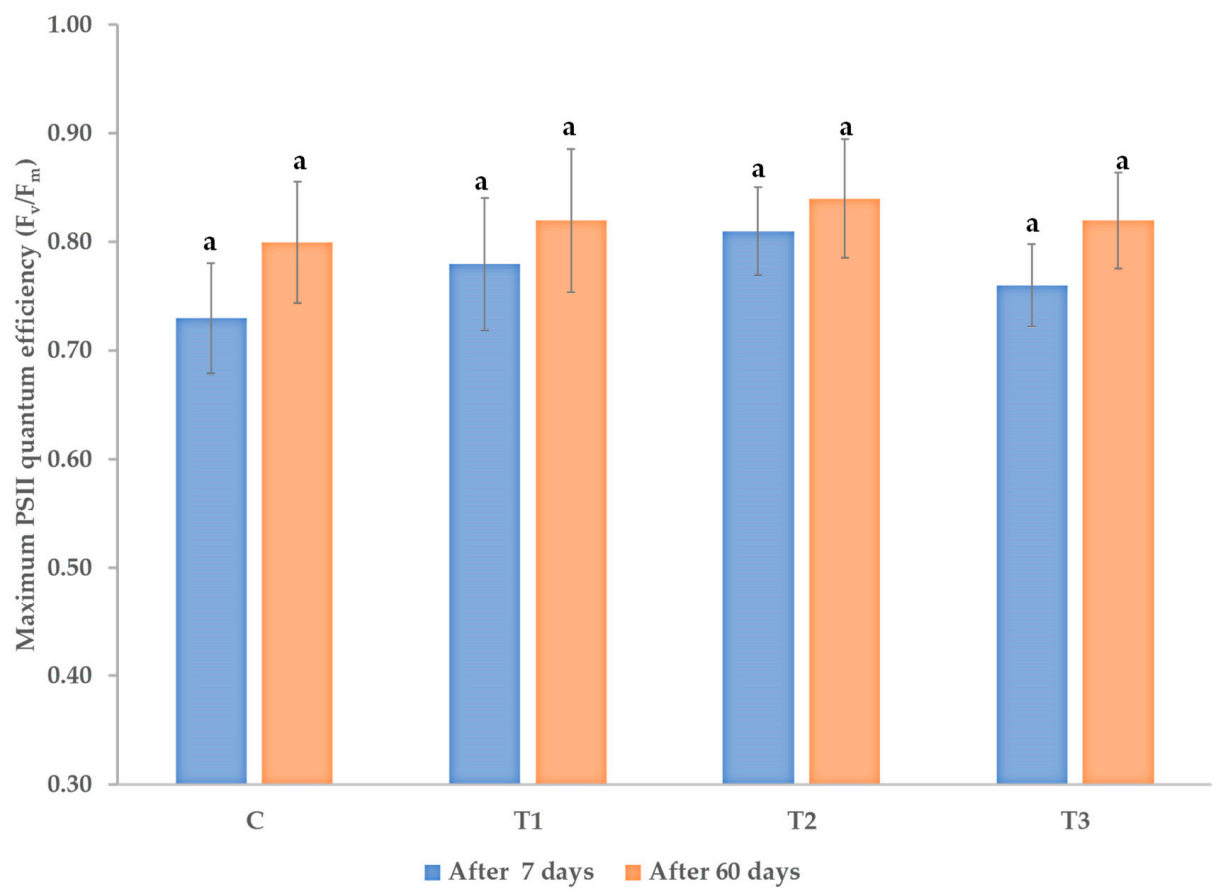

(b)

Figure 2. (a) Stomatal conductance $\left(\mathrm{nmol} / \mathrm{m}^{2} \mathrm{~s}\right.$ ) and (b) maximum PSII quantum efficiency of $P$. caerulea plants after seven days from the first treatment and after 60 days from the first treatment with plant biostimulants. C - control (no treatment with plant biostimulants, treated only with water); $\mathrm{T}_{1}$-foliar treatment with Trichoderma consortium suspension, $10^{6} \mathrm{cfu} / \mathrm{mL}$, equiv. to $10^{11}$ spores/ha; $\mathrm{T}_{2}$-foliar treatment with Trichoderma consortium suspension, $10^{8} \mathrm{cfu} / \mathrm{mL}$, equiv. to $10^{13}$ spores/ha; $\mathrm{T}_{3}$-foliar treatment with the reference product, consisting of plant extracts, essential oils and fatty acids in an oil/water emulsion, and extract of the seaweed Ascophyllum nodosum, equiv. to $3 \mathrm{~L} / \mathrm{ha}$. The values presented are means \pm standard error $(n=40$ plants). Columns labeled with different letters, compared between the different treatments $(C, T 1, T 2$, and T3) within each time period (after 7 days and, respectively, after 60 days) are significantly different at $p<0.05$.

\subsection{Effects on Leaf Ultrastructure}

The plant treatment with the Trichoderma consortium at the higher concentration resulted in an increased number of chloroplasts in spongy parenchyma, with larger surface when compared to the control-Table 1, Figure 3.

Table 1. Number and surface (in $\mu^{2}$ ) of the chloroplasts from spongy parenchyma of P. caerulea plants treated with plant biostimulants.

\begin{tabular}{|c|c|c|}
\hline Variant & $\begin{array}{l}\text { Chloroplast Number } \\
\quad(n=100)\end{array}$ & $\begin{array}{l}\text { Chloroplast Surface, } \\
\mu^{2}(n=40)\end{array}$ \\
\hline $\begin{array}{l}\mathrm{C} \text { - control (no treatment with plant biostimulants, treated only } \\
\text { with water) }\end{array}$ & $7.9 \pm 0.4 b$ & $4.8 \pm 0.8 \mathrm{~b}$ \\
\hline $\begin{array}{l}\mathrm{T}_{1} \text {-foliar treatment with Trichoderma consortium suspension, } \\
\qquad 10^{6} \mathrm{cfu} / \mathrm{mL} \text {, equiv. to } 10^{11} \text { spores } / \text { ha }\end{array}$ & $8.4 \pm 0.3 b$ & $5.3 \pm 0.6 b$ \\
\hline $\begin{array}{c}\mathrm{T}_{2} \text {-foliar treatment with Trichoderma consortium suspension, } \\
110^{8} \mathrm{cfu} / \mathrm{mL} \text {, equiv. to } 10^{13} \text { spores } / \mathrm{ha}\end{array}$ & $12.8 \pm 0.7 \mathrm{a}$ & $9.2 \pm 1.1 \mathrm{a}$ \\
\hline $\begin{array}{l}\mathrm{T}_{3} \text {-foliar treatment with a reference product, consisting of plant } \\
\text { extracts, essential oils and fatty acids in an oil/water emulsion, } \\
\text { and extract of the seaweed Ascophyllum nodosum, equiv. to } 3 \mathrm{~L} / \mathrm{ha}\end{array}$ & $8.9 \pm 0.6 b$ & $6.2 \pm 0.9 b$ \\
\hline
\end{tabular}



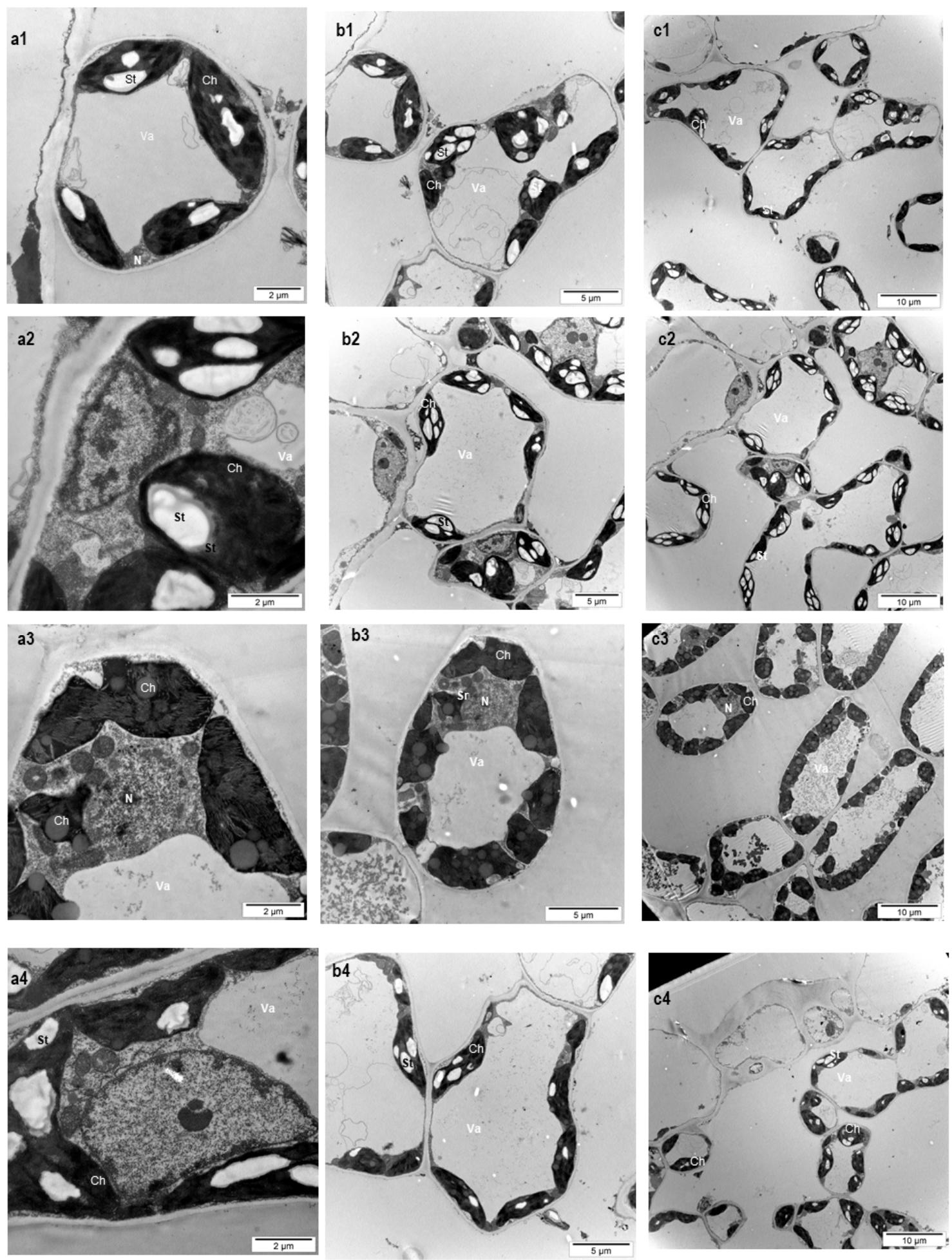

Figure 3. Ultrastructural aspects of the spongy parenchyma cells of $P$. caerulea leaves after 60 days from the first treatment with plant biostimulants; (a1,b1,c1): C, control (no treatment with plant biostimulants, treated only with water); (a2, b2,c2): $\mathrm{T}_{1}$, foliar treatment with Trichoderma consortium suspension, $10^{6} \mathrm{cfu} / \mathrm{mL}$, equiv. to $10^{11}$ spores/ha; $(\mathbf{a} 3, \mathbf{b} 3, \mathrm{c} 3): \mathrm{T}_{2}$-foliar treatment with Trichoderma consortium suspension, $10^{8} \mathrm{cfu} / \mathrm{mL}$, equiv. to $10^{13}$ spores/ha; $(\mathbf{a} 4, \mathbf{b} 4, \mathbf{c 4}): \mathrm{T}_{3}$, foliar treatment with a reference product, consisting of plant extracts, essential oils and fatty acids in an oil/water emulsion, and extract of the seaweed Ascophyllum nodosum, equiv. to $3 \mathrm{~L} / \mathrm{ha}$. Ch-chloroplast; Va-Vacuole; $\mathrm{St}$-Starch grains; $\mathrm{N}$-nucleus; $\mathbf{a}, \mathbf{b}, \mathbf{c}$ - different magnifications. 
Following application of the higher concentration of Trichoderma consortium spores, the number of chloroplasts increased by $62.02 \%$ and the surface of the chloroplasts almost doubled-an increase of $91.66 \%$. The chloroplast enlargement was not statistically significant in the case of the leaves that were subjected to treatment with the lower amount of the Trichoderma consortium or with the reference product. In the case of the lower Trichoderma consortium concentration, the overall anatomy of the spongy parenchyma cells tissue was not significantly changed. The chloroplast number and surface did not increase significantly. The treatment with the reference product, wherein volatile compounds and elicitors are included, tended to change the chloroplast number and the chloroplast surface from the cell spongy parenchyma cells. However, this tendency is not statistically significant. The analyzed spongy parenchyma cells ultrastructure suggests that the application of the Trichoderma consortium at the concentration of $10^{8} \mathrm{ufc} / \mathrm{mL}$ leads to successful colonization of P. caerulea phyllosphere.

\subsection{Polyphenols, Flavonoids, and Antioxidant Activity in Leaves of the Treated Plants}

The marketable yield of the P. caerulea nutraceutical crop is represented by the aerial parts, which can be harvested without compromising the development of the plants in the next year. Maceration in $\mathrm{Et}(\mathrm{OH})$-water $70 \%(v / v)$ solution was chosen for the extraction of polyphenols and flavonoids from dried and ground aerial parts of P. caerulea, in accordance with our previous work, in which we found that this method recovered the highest concentration of polyphenols and flavonoids from this passion plant material [73]. The treatments with the plant biostimulants promoted the accumulation of polyphenols and flavonoids into the aerial parts of $P$. caerulea plants, as in Figure 4.



Figure 4. Total polyphenols (mg GAE/g dw) and total flavonoids (mg QE/g dw) in the hydroalcoholic extracts from aerial parts of the P. caerulea plants after seven days from the first treatment and after 60 days from the first treatment with plant biostimulants. C-control (no treatment with plant biostimulants, treatment only with water); $\mathrm{T}_{1}$ - foliar treatment with Trichoderma consortium suspension, $10^{6} \mathrm{cfu} / \mathrm{mL}$, equiv. to $10^{11}$ spores $/$ ha; $\mathrm{T}_{2}$-foliar treatment with Trichoderma consortium suspension, $10^{8} \mathrm{cfu} / \mathrm{mL}$, equiv. to $10^{13}$ spores/ha; $\mathrm{T}_{3}$-foliar treatment with a reference product, consisting of plant extracts, essential oils, and fatty acids in an oil/water emulsion, and extract of the seaweed Ascophyllum nodosum, equiv. to $3 \mathrm{~L} / \mathrm{ha}$. Values presented are means \pm standard error $(n=12$ replicates). Columns labeled with different letters within each parameter are significantly different at $p<0.05$. 
The accumulation of both polyphenols and flavonoids was most significant in plants that were treated with the higher concentration of the Trichoderma plant biostimulant consortium, $10^{8} \mathrm{cfu} / \mathrm{mL}$, more than $35 \%$ when compared to the control for both sampled periods ( 7 days and 60 days after the first treatment). In the case of the lower concentration of the Trichoderma consortium, the accumulation of higher quantities of polyphenols and flavonoids was not statistically significant after 60 days from the first treatment. However, for the plant material that was sampled after seven days, the application of the lower concentration of the Trichoderma consortium resulted in a significant increase in the total polyphenols and flavonoids-by more than $10 \%$ higher than the water treated control. The reference product promoted a significant accumulation of total flavonoids after the first treatment - an almost $24 \%$ increase of the total flavonoids when compared to the control. The effect resulting from the reference plant biostimulant was less significant after 60 days, when the increase in the total flavonoids was around $14 \%$.

A similar effect was observed for the antioxidant activity, as in Figure 5a,b. The highest concentration of the Trichoderma plant biostimulant consortium, $10^{8} \mathrm{cfu} / \mathrm{mL}$, resulted in the highest antioxidant activity in both assays (DPPH and TEAC).

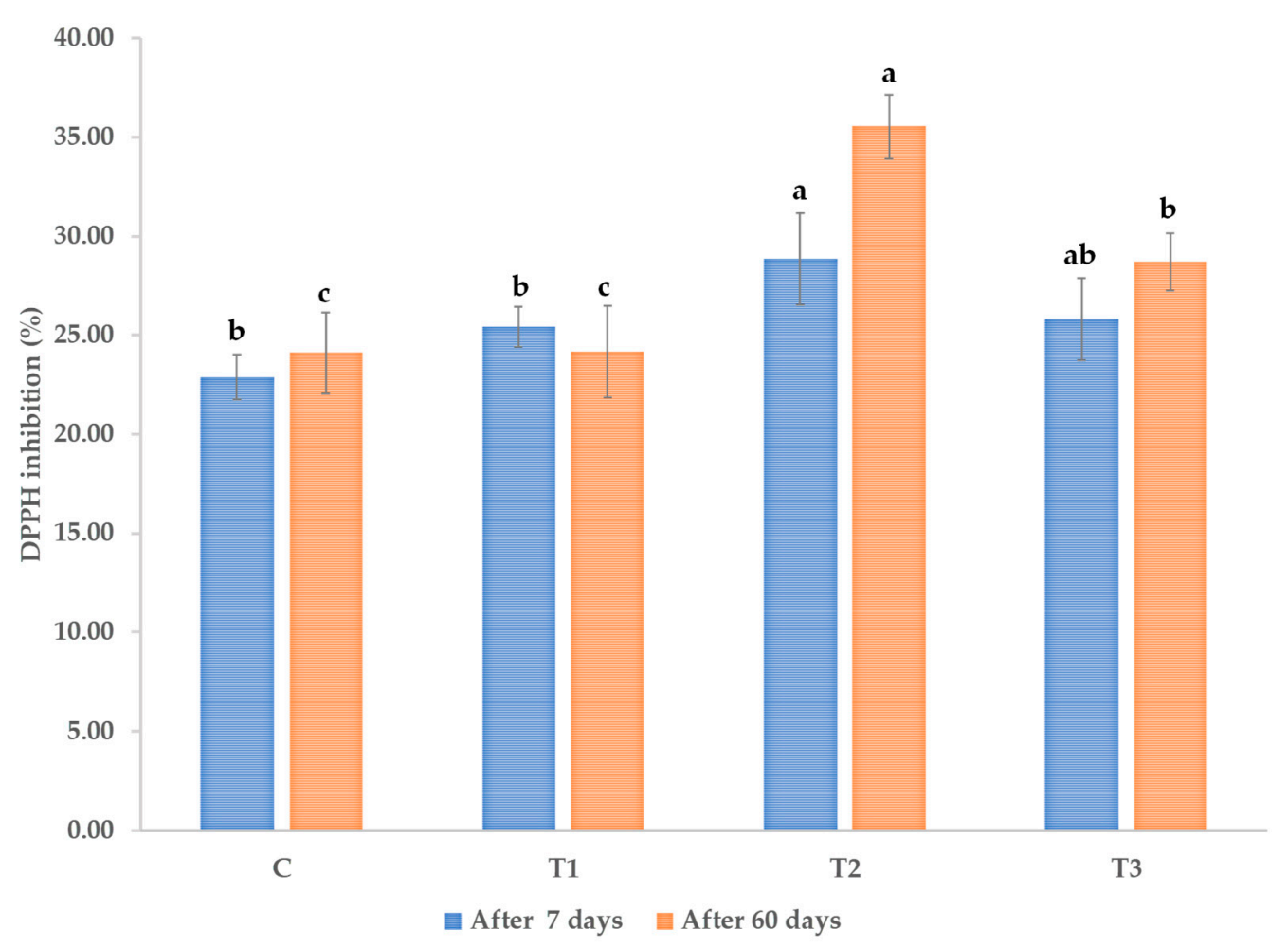

(a)

Figure 5. Cont. 


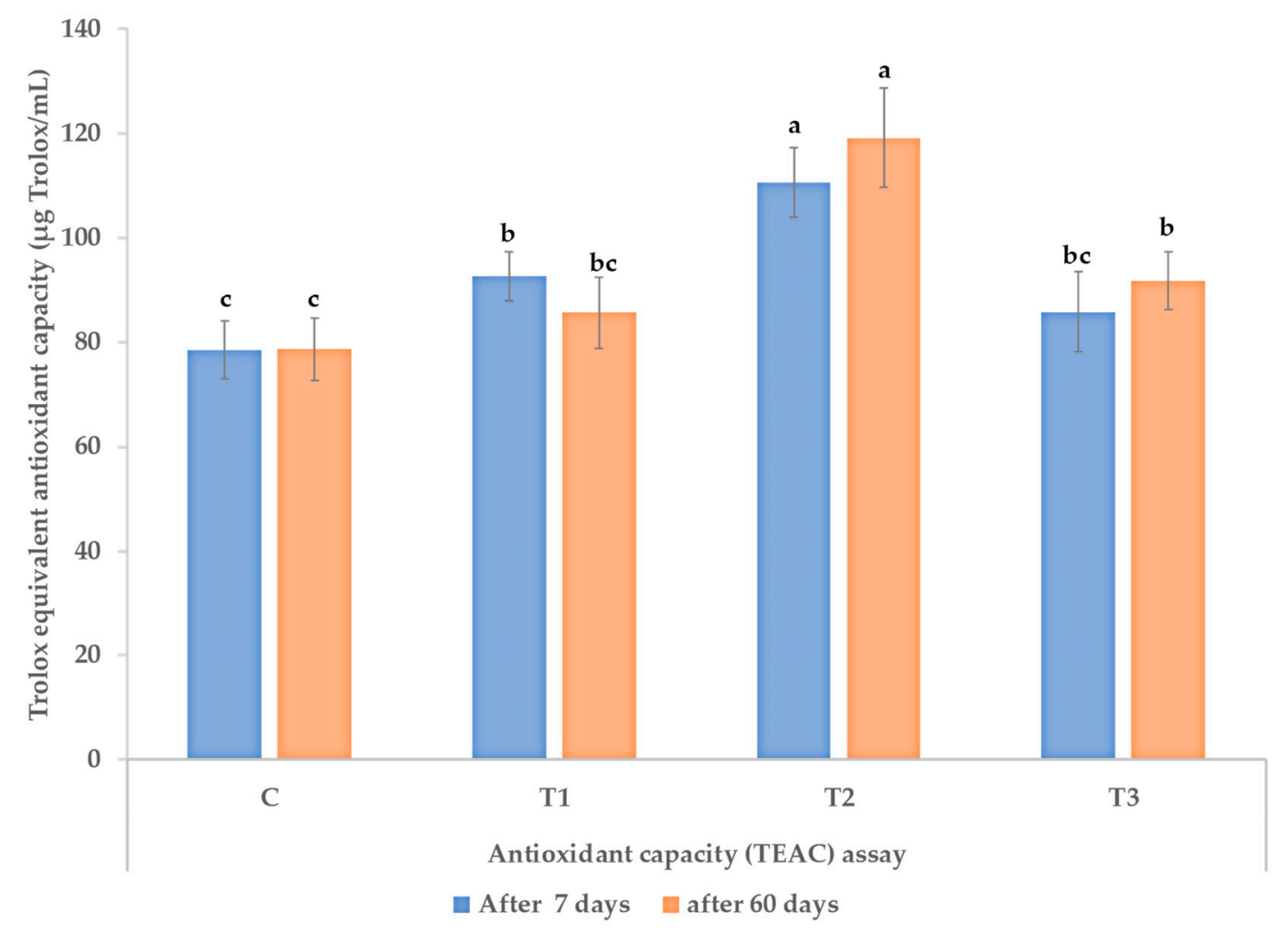

(b)

Figure 5. Antioxidant activity of the hydroalcoholic extract of aerial parts of the $P$. caerulea plants, determined as the ability to scavenge the formation of the DPPH (2,2-diphenyl-1-picryl-hydrazyl-hydrate) free radicals (a) and TEAC (Trolox equivalent antioxidant capacity) (b), after seven days from the first treatment and after 60 days from the first treatment. $\mathrm{C}$ - control (no treatment with plant biostimulants, treatment only with water); $\mathrm{T}_{1}$ - foliar treatment with the Trichoderma consortium suspension, $10^{6} \mathrm{cfu} / \mathrm{mL}$, equiv. to $10^{11}$ spores $/$ ha; $\mathrm{T}_{2}$-foliar treatment with the Trichoderma consortium suspension, $10^{8} \mathrm{cfu} / \mathrm{mL}$, equiv. to $10^{13}$ spores $/$ ha; $\mathrm{T}_{3}$-foliar treatment with a reference product, consisting of plant extracts, essential oils and fatty acids in an oil/water emulsion, and extract of the seaweed Ascophyllum nodosum, equiv. to $3 \mathrm{~L} / \mathrm{ha}$. The values presented are means \pm standard error $(n=12$ replicates). Columns labeled with different letters, compared between the different treatments $(C, T 1, T 2$, and T3) within each time period (after 7 days and, respectively, after 60 days) are significantly different at $p<0.05$.

After seven days from the first treatment, the antioxidant activities of the hydroalcoholic extracts from passion plants that were treated with Trichoderma, $10^{8} \mathrm{cfu} / \mathrm{mL}$ were $26.12 \%$ and $40.35 \%$ higher than the control, as determined by the DPPH method and the ABTS/TEAC method, respectively. After 60 days from the first treatment, the increase became more pronounced in the case of the DPPH assay, $47.37 \%$ higher activity of extracts from plants treated with Trichoderma, $10^{8} \mathrm{cfu} / \mathrm{mL}$, than the control. For the TEAC assay, the increase as compared to the control exceeded $50 \%$. The effects of the lower concentration of Trichoderma plant biostimulant treatment, $10^{6} \mathrm{cfu} / \mathrm{mL}$, were only statistically significant in the case of the plant material sampled after seven days from the first treatment. In the case of the antioxidant activity determined by the TEAC assay, the activity of the lower concentration was $17.93 \%$ higher than the activity of the extracts from the control plants after seven days. Treatment with the reference products containing elicitors from plants and seaweeds resulted in a significant increase in the antioxidant activity that was assayed by the DPPH method, at both timepoints $(12.84 \%$ at seven days and $19.07 \%$ at 60 days after the first treatment)). In the case of the TEAC method the increase was significant only at 60 days from the first treatment- $16.63 \%$ as compared to the control. 


\subsection{Cytocompatibility of the Extracts from the Treated Leaves}

The stimulation of bioactive compounds accumulation in $P$. caerulea leaves, especially of polyphenols and flavonoids, could lead to combinations with reduced safety [83]. High doses of polyphenols proved to be toxic in some cases [84]; therefore, a screening of the safety of treated plant extracts was considered to be necessary. An in vitro method based on cultured cell viability assay was selected for safety screening of the blue passion flower extracts. Such techniques, corresponding to the reduction-replacement-refinement ethical principles of laboratory animal tests, offer results that are consistent with ingestion/in vivo studies [85] and also have the advantages of rapidity and lower costs when compared to the in vivo techniques [86].

The in vitro biocompatibility of the treated leaf extracts was assessed on a stabilized line of mouse fibroblast NCTC L929 cells, while using the MTT (dimethylthiazol-diphenyltetrazolium bromide) assay. This colorimetric assay evaluates the activity of mitochondrial succinate dehydrogenase (which reduces the soluble MTT tetrazolium salt to the insoluble blue MTT formazan product) as a marker of cell viability. The results that were obtained after $48 \mathrm{~h}$ of cell incubation did not demonstrate the presence of cytotoxic compounds. All of the tested extracts, which were obtained from P. caerulea-treated leaves, proved to be compatible with the mouse fibroblast NCTC L929 cell culture in the tested concentration range of $50-150 \mu \mathrm{g} / \mathrm{mL}$, as in Figure 6. The pattern of cytocompatibility shows some differences between the plant materials, depending on the sampling date, treatment, and concentration applied. At low $(50 \mu \mathrm{g} / \mathrm{mL})$ and intermediate $(100 \mu \mathrm{g} / \mathrm{mL})$ concentration tested, some of the variants induced a slight stimulation of the viability (low dose $-\mathrm{C}$ and T3 sampled at 7 days, T2 and T3 sampled at 60 days; intermediate dose $-\mathrm{T} 2$ at 7 days, $\mathrm{T} 3$ and $\mathrm{T} 4$ at 60 days). Other variants induced a slight decrease in the viability (low dose $-\mathrm{C}$ and $\mathrm{T} 1$ at 7 days, $\mathrm{C}$ and $\mathrm{T} 3$ at 60 days; intermediate dose $-\mathrm{C}, \mathrm{T} 2$ and T3 at seven days, T1 at 60 days). The highest tested concentration of $150 \mu \mathrm{g} / \mathrm{mL}$ slightly reduced the cell viability for all of the tested extracts from all treatments.

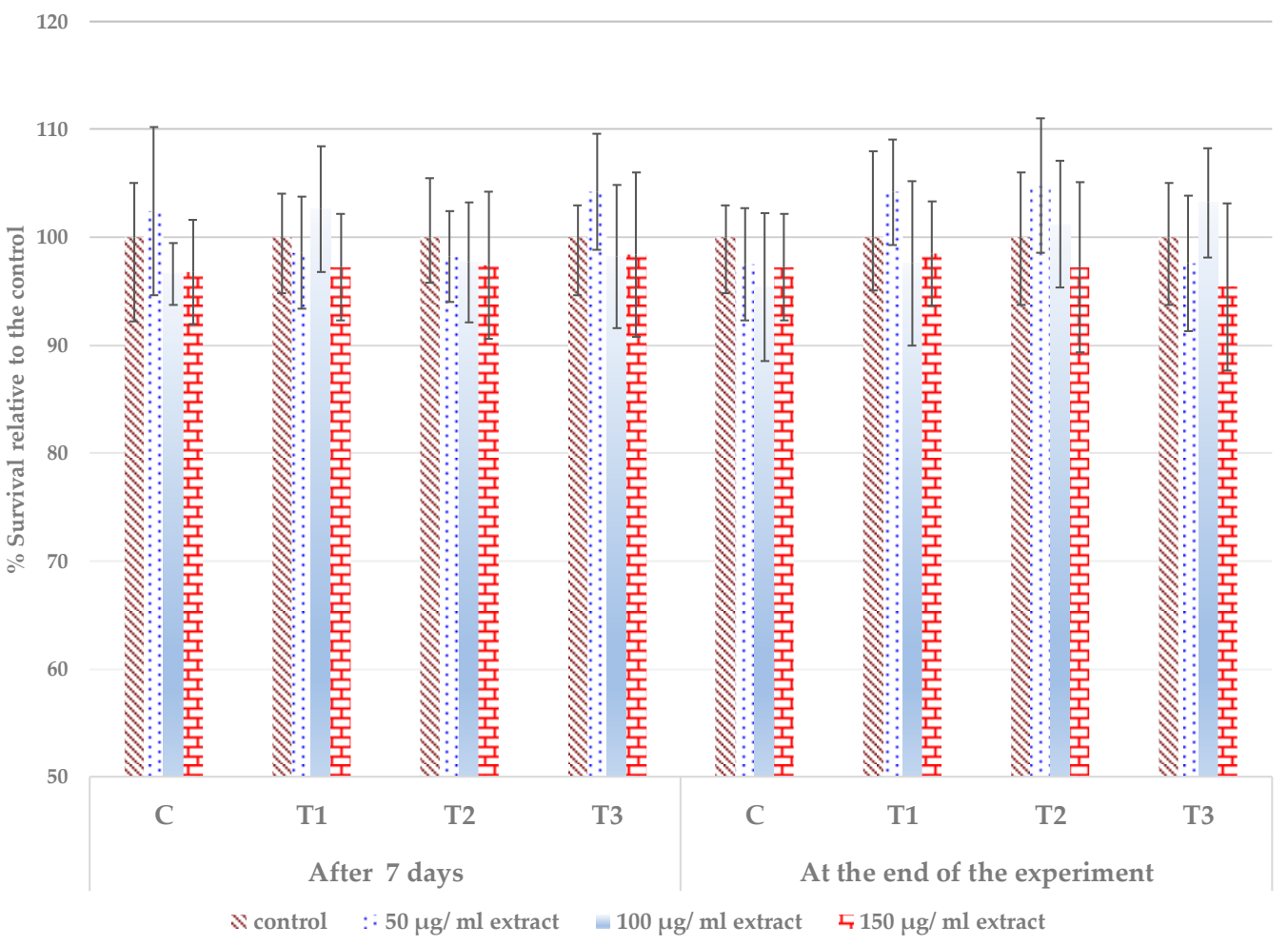


Figure 6. Mouse fibroblast NCTC L929 cell viability after incubation for $48 \mathrm{~h}$ with different concentrations of a hydroalcoholic extract of aerial parts of the P. caerulea plants sampled after seven days from the first treatment and after 60 days from the first treatment with plant biostimulants. $\mathrm{C}$ - plant control (no treatment with plant biostimulants, treated only with water); T1-foliar treatment with the Trichoderma consortium suspension, $10^{6} \mathrm{cfu} / \mathrm{mL}$, equiv. to $10^{11}$ spores/ha; T2-foliar treatment with the Trichoderma consortium suspension, $10^{8} \mathrm{cfu} / \mathrm{mL}$, equiv. to $10^{13}$ spores/ha; T3-foliar treatment with a reference product, consisting of plant extracts, essential oils, and fatty acids in an oil/water emulsion, and the extract of the seaweed Ascophyllum nodosum, equiv. to $3 \mathrm{~L} / \mathrm{ha}$. The values presented are means \pm standard errors ( $n=12$ replicates) and are not statistically different.

However, these differences were not significant. Usually, a tested sample is considered to be cytotoxic/not cytocompatible when the viability is reduced to less than $80 \%[87,88]$. The cell morphology was normal, without alteration of the cell membrane structure-Supplementary Material, Figure S1. This finding supports the good cytocompatibility of the extracts from the treated P. caerulea leaves.

\subsection{Effects on Yield and Yield Quality}

The main aim of treatment with the Trichoderma plant biostimulant consortium was to increase the yield and improve the yield quality following the successful colonization of the phyllosphere by the applied plant beneficial strains. The treatments with the Trichoderma consortium at the higher spore concentration resulted in a better development of the passion plant canopy, with higher leaf surface, increased biomass accumulation, and increased marketable yield. Together with an increased biomass accumulation, a higher level of bioactive compounds accumulated in the aerial parts of the treated plants. At 60 days after the first treatment, the production of the human health-promoting compounds in the P. caerulea nutraceutical crop was significantly increased by the application of the Trichoderma plant biostimulant consortium at a concentration of $10^{8} \mathrm{cfu} / \mathrm{mL}$. In Table 2, we summarized the marketable yield of the treated nutraceutical plants, integrating the quality features (total polyphenols and total flavonoids) with the marketable yield-i.e., the quantity of the leaves that could be harvested without compromising the P. caerulea perennial plant future development.

Table 2. Marketable dried yield of aerial plants, total polyphenols, and total flavonoids in the harvested biomass from the P. caerulea plants that were treated with the plant biostimulants.

\begin{tabular}{ccccc}
\hline No. & Treatment & $\begin{array}{c}\text { Marketable Yield, } \\
\text { Dried Weight } \\
\text { (Kg/15 Plants) }\end{array}$ & $\begin{array}{c}\text { Total Polyphenols } \\
\text { Harvested (g/15 } \\
\text { Plants) }\end{array}$ & $\begin{array}{c}\text { Total Flavonoids } \\
\text { Harvested (g/15 } \\
\text { Plants) }\end{array}$ \\
\hline $\mathrm{C}$ & Control (untreated) & $0.90 \pm 0.04 \mathrm{~b}$ & $15.48 \pm 2.06 \mathrm{~b}$ & $11.16 \pm 2.48 \mathrm{~b}$ \\
\hline $\mathrm{T}_{1}$ & $\begin{array}{c}\text { Trichoderma } 10^{6} \mathrm{ufc} / \mathrm{mL}, \\
\text { equiv. } 2 \times 10^{11} \text { spores/ha }\end{array}$ & $0.92 \pm 0.06 \mathrm{~b}$ & $16.37 \pm 2.82 \mathrm{~b}$ & $11.77 \pm 2.84 \mathrm{~b}$ \\
\hline $\mathrm{T}_{2}$ & $\begin{array}{c}\text { Trichoderma } 10^{8} \mathrm{ufc} \\
\text { equiv. } 2 \times 10^{13} \text { spores/ha }\end{array}$ & $1.15 \pm 0.05 \mathrm{a}$ & $27.14 \pm 4.73 \mathrm{a}$ & $21.39 \pm 4.23 \mathrm{a}$ \\
\hline $\mathrm{T}_{3}$ & $\begin{array}{c}\text { Reference product, plant oil, } \\
\text { algae, and plant extract }\end{array}$ & $1.01 \pm 0.08 \mathrm{ab}$ & $18.48 \pm 4,27 \mathrm{ab}$ & $14.24 \pm 4.05 \mathrm{~b}$ \\
\hline
\end{tabular}

The values presented are means \pm standard errors ( $n=4$ replicates). Values followed by the same letter are statistically similar for a specific parameter, according to $\operatorname{LSD}(p<0.05)$.

The accumulation of the total polyphenols and flavonoids was $75 \%$ and, respectively, more than $90 \%$ higher in the marketable yield when compared to the water-treated control. The difference between the effects that were produced in the passion plants by the two concentrations of the Trichoderma plant biostimulant consortium was evident for the leaf growth rate, which was significantly higher at the higher spore concentration, $10^{8} \mathrm{cfu} / \mathrm{mL}$, than at the lower spore concentration, $10^{6} \mathrm{cfu} / \mathrm{mL}$, as shown above (Figure 1c). A high growth rate of the treated leaves was demonstrated for the treatment with the reference plant biostimulant product - this effect is probably related to both active ingredients 
from seaweeds/plant extracts and the micro-nutrient contents in this reference biostimulant. The higher leaf growth rate determines the marketable biomass yield, which was the highest for the higher concentration of Trichoderma and for the reference products. In plants treated with the Trichoderma consortium $\left(10^{8} \mathrm{cfu} / \mathrm{mL}\right)$, the dried weight of the harvestable leaves increased by more than $27 \%$ as compared to the control treated with water and reached $1.15 \mathrm{Kg}$ of dried plant material for 15 harvested plants, as in Table 2. The significant increase of polyphenols and flavonoids accumulation following treatment with the Trichoderma consortium at the higher concentration determined a higher yield of the bioactive compounds in the marketable production.

\section{Discussion}

Despite the fact that the Trichoderma strains are generally considered to be specific to soil and plant root systems - the rhizosphere and/or rhizoplane habitat-efficient strains have been used for decades as biological control agents in the phyllosphere, the microbial habitat that is specific to the aerial parts of the plants [89]. Phyllosphere/phylloplane fungi are challenged by the much lower nutrient availability as compared to the rhizosphere and by higher abiotic stress-i.e., moisture, temperature, higher temperature and humidity variations, and ultra-violet light. However, multifunctional/multifaceted strains, which originate from the rhizosphere, such as those that are used in this study, have been proven to have plant biostimulant effects after application as foliar treatment. T. harzianum T22, a strain that is largely used for the production of commercial bioproducts, originating from soil and well-known for its rhizosphere competence [10], was applied for the treatment of the grape phyllosphere [35]. A volatile secondary metabolite, 6-pentyl-2H-pyran-2-one-6-PP, specific to Trichoderma, was also applied as a reference for the T22 treatment. Repeated applications of foliar treatments with the T22 strain $\left(10^{8}\right.$ spores/liter) and 6-PP (1 $\mu \mathrm{M}$ solution) resulted in increased crop yield, enhanced the accumulation of polyphenols, and induced higher antioxidant activity. 6-PP was more active in inducing the antioxidant activity in raisins ( $+60.3 \%)$ when compared to T-22- $48.7 \%$.

In the above-mentioned study, repeated treatment was the strategy used to promote the establishment of the applied strain in the phyllosphere habitat. Other successful strategies for promoting the colonization of the phyllosphere/phylloplane by inoculated strains include the manipulation of the abiotic conditions, i.e., humidity [90], inclusion into controlled released formulations, which specifically release propagules into the leaf environment [91], and the application of higher propagule density [92]. In this study, we used the strategy related to a higher density of the initial inoculum, while only using the spores (with a high proportion of chlamydospores) that were collected after cultivation on specific media [68,69] and that survive well in the environment [93]. A concentration of $10^{8}$ spores/mL, 1000-fold higher than that used for T22 applied on grape [35], causes a long-lasting effect and a significant increase in bioactive compounds in P. caerulea. The lower concentration applied, $10^{6}$ spores, probably does not ensure enough inoculum for the Trichoderma to compete and colonize the phyllosphere niche, especially when the canopy of the passion plant increases due to leaf development. In small leaves, with small surface, the lower concentration of the applied spores also has a significant effect (at seven days after the first treatment). However, after the second treatment, when the surface of the leaf increases, the applied lower concentration of the Trichoderma consortium does not continue to influence the treated plants, most probably due to the failure of colonization of the phyllosphere.

The colonization of the leaves by the Trichoderma consortium was associated with enhanced growth of the $P$. caerulea plants. As previously mentioned, both strains used for the applied Trichoderma consortium produce bioactive volatile compounds, including 6-PP [62,63], are antagonists of major plant pathogens [63,64], protect and stimulate vegetable growth [65], and produce enzymes and other active molecules (e.g., cerato-platanin) that promote the degradation of lignocellulose material [66,67]-microbial elicitors (pathogen or microbial-associated molecular patterns-PAMPs, or, respectively, MAMPs) [13,14]. PAMPs and MAMPs trigger the innate immunity-PTI (PAMPs-triggered immunity) and MTI (MAMPs triggered immunity) [94]. Trichoderma is considered to be a model to study these microbial effectors of the innate immunity/plant defence [95]. 
Chloroplasts play an essential role in plant innate immunity at the cellular level [96,97]. These organelles are not involved only in the primary metabolism, such as light energy harvester or for photosynthesis of carbohydrates, but are also the sites for the biosynthesis and transmission of signals that are involved in plant defence/innate immunity responses [98]. To the best of our knowledge, there are no reports that relate Trichoderma triggered immunity to the ultrastructure or functions of chloroplasts, despite the fact that Trichoderma is a model for plant defence/innate immunity triggering [95]. Very recently, it was communicated that L-amino Acid Oxidase secreted by Trichoderma triggers the innate immunity by targeting Chlorophyll a/b Binding Proteins from chloroplasts [99]. Our ultrastructural analysis of the spongy parenchyma demonstrates an increase in the number and surface/volume of the chloroplasts from treated plants. Such finding suggests that the chloroplasts play a role in the plant defense activation exerted by Trichoderma, which gives a new perspective of the well-known enhancement of the photosynthetic capacity that is determined by Trichoderma treatments. The promotion of chloroplast development in the case of treatment with the higher concentration of Trichoderma spores is another indirect evidence, besides the morpho-physiological features, of the successful colonization of the phyllosphere promoted by the higher applied concentration.

The environmental factors are important for the effects of plant biostimulants. By definition, plant biostimulants enhance plant tolerance to abiotic stress [100]. In horticultural crops, plant biostimulants are considered to be important agronomic tool to mitigate environmental/abiotic stress effects [101]. Therefore, experimental field tests of plant biostimulants must be done with plants that have been subjected to environmental/abiotic stress conditions. The main stress for the P. caerulea plants which we used in our field experiments is related to light intensity. P. caerulea, as the other plants from Passiflora genera, is a liana, a woody vine that climbs on trees and develops under shade conditions. Passion plants are cultivated as shrubs, in full sunlight. However, the optimal photosynthetic radiation for Passiflora plants was shown to be $\sim 25 \%\left(300-650 \mu \mathrm{mol} \mathrm{m}{ }^{-2} \mathrm{~s}^{-1}\right)$ or $\sim 50 \%\left(400-750 \mu \mathrm{mol} \mathrm{m}^{-2} \mathrm{~s}^{-1}\right)$ from the corresponding photosynthetically active radiation (PAR) that is specific to full sunlight (1000-1500 $\mu \mathrm{mol} \mathrm{m} \mathrm{m}^{-2} \mathrm{~s}^{-1}$, minimum-maximum) [102]. The light intensity stress could also explain our findings that are related to the lack of effect of the plant biostimulant treatments on the photosynthetic efficiency determined by the chlorophyll fluorescence assay.

Light intensity stress in plants is associated with higher production of reactive oxygen species (ROS) [103]. It was shown that Trichoderma treatments reduce the effects that are produced on plants by various biotic or abiotic stresses by the modulation of the reactive oxygen species and reduction of their accumulation at pathological level [104-106]. A similar mechanism, together with the increase in the number and surface of chloroplasts, could be probably involved in our study, the treatment inducing protection of the blue passion plant against high light intensity by a reduction of accumulation of reactive oxygen species. It was shown that the ultrastructure of chloroplasts (including number and surface) is a reliable marker for stress, including light stress [76]. Therefore, the increased number of larger chloroplasts could be the result of efficient light intensity stress mitigation by the Trichoderma consortium that is established within the leaf habitat, following the application of the higher concentration of the more resistant chlamydospores.

Treatments with Trichoderma are well-known to increase the photosynthetic plant capability [24]. Our focus on the ultrastructure of the spongy parenchyma cells was motivated by their important function in photosynthesis, during both light and dark phases. Such cells provide uniformity in light absorption by the leaves [107]. Due to their organization, with spaces on the top of the lower epidermis (wherein more stomata are usually located), spongy parenchyma cells are more efficient in performing dark phase photosynthesis- $\mathrm{CO}_{2}$ fixation [108]. Additionally, the spongy parenchyma tissue porosity is essential for mesophyll diffusion conductance to $\mathrm{CO}_{2}$, being recognized at present as being a major limiting factor for photosynthesis and for photosynthetic resource use efficiency [109]. Recent studies demonstrated that spongy parenchyma cells are also photosynthetically active under UV stress [110].

In a previous study, we tested the influence of the treatments with the same Trichoderma consortium, applied at $10^{8} \mathrm{cfu} / \mathrm{mL}$, on $P$. caerulea leaf development and leaf morpho-anatomical features. We 
reported that the mesophyll from the treated plants is more voluminous, with both palisade and spongy parenchyma cells being more developed and with larger plant cell walls [72]. In the present study, we investigated the changes in the ultrastructural features and established the importance of spore concentration for a successful long-term phyllosphere colonization, together with other aspects, such as the yield and yield quality.

The ultrastructural analysis of spongy parenchyma cells confirmed our previous light microscopy determinations. It reveals that the Trichoderma treatment at $10^{8} \mathrm{cfu} / \mathrm{mL}$ determines not only an increase in the number and surface of the chloroplasts, but also visibly reduces the volume and number of the starch grains (Figure 3). The reduction of chloroplast starch grains suggests a more efficient translocation of photosynthesized carbohydrates from chloroplasts to the rest of the cell and/or to the phloem. Various stresses, such as high temperature [111], salt stress and gamma rays [112], or heavy metal stress [113], were reported to generate large starch grains in the chloroplasts, due to the disruption of the photosynthesized carbohydrates translocation.

The yield quality is also improved in the Trichoderma-Passiflora interaction, when the Trichoderma consortium is applied at higher spore rate. The bioactive compounds that accumulate in the passion plants that are treated with the Trichoderma consortium are polyphenols and flavonoids. This is important for the yield quality of $P$. caerulea-we have already presented the involvement of the polyphenols and flavonoids as the main active ingredients that are responsible for the effects of passion flowers on human health and wellbeing [49,50].

Enhanced polyphenols accumulation suggests the activation of their main biosynthesis pathway in plants, the phenylpropanoid pathway [114]. Recently, it was demonstrated that the Trichoderma treatment activates this pathway [115]. The enlargement of the plant cell wall under the effect of treatment with Trichoderma consortium spores, which we previously reported [72], is an indirect proof of the phenylpropanoid pathway activation and it is directly associated with polyphenol accumulation. The phenylpropanoid pathway is connected to lignin biosynthesis, and lignin is one of the main components of the plant cell wall [116]. The phenylpropanoid pathway association with the shikimate and the quinate pathways also cause the accumulation of hydroxycinnamic acids [117], polyphenols that anchor the hydrophobic and hydrophilic parts of the plant cell wall [118]. Therefore, the activation of the phenylpropanoid pathway leads to the accumulation of polyphenols, cell wall proliferation, and enhanced plant resistance to biotic and abiotic stress.

The antioxidant activity of polyphenols and flavonoids has been related to health benefits [51-53]. In this study, we found a correlation between the accumulation of the antioxidant polyphenols and flavonoids and decreased stomatal conductance (a proxy for water use efficiency). Other studies demonstrated that antioxidant polyphenols/flavonoids are involved in enhanced tolerance to drought/water stress, tolerance that is induced by treatment with the plant biostimulant Trichoderma $[20,119]$. The effects are probably related to the cross-talk of the antioxidant bioactive compounds with the reactive oxygen species (ROS) and their signaling cascade [120]. The role of ROS quenching and homeostasis in the regulation of stomatal conductance and water use efficiency was recently highlighted [121]. The accumulation of polyphenols causes enhanced tolerance to abiotic stress [114]. Therefore, we conclude that the application of the Trichoderma consortium, which activates plant secondary metabolism and stimulates the accumulation of antioxidant polyphenols and flavonoids, also has an agronomic benefit, in addition to the effects on human-health promoting properties of crop products. In nutraceutical crops, such multi-level effects, which result from the interaction of the cultivated plants with multi-functional/plant biostimulant Trichoderma strains, have a significant economic effect, due to the combination of a higher yield and better quality/health-promoting properties.

\section{Conclusions}

The Trichoderma consortium formed by two strains from the INCDCP-ICECHIM collection, $T$. asperellum T36 NCAIM F 001434 and T. harzianum, Td50b NCAIM F001412, being applied at the concentration of $10^{8} \mathrm{cfu} / \mathrm{mL}$, induced a significant long-term stimulation of leaf growth and of bioactive 
compounds accumulation. Plant yield and quality both increased after the Trichoderma consortium treatment. The observed effects on plant physiology and plant cell wall proliferation suggest enhanced resistance of the treated plants to stress. Applying a high rate of resistant Trichoderma strains spores (e.g., chlamydospores) seems to promote long-term phyllosphere colonization and could represent a more efficient strategy for obtaining higher crop yield and quality, by reducing the number of treatments.

\section{Patents}

A patent application, RO 131827 A2, was filled in relation to the Trichoderma consortium presented in this paper. This consortium, formed by two strains from the INCDCP-ICECHIM collection, $T$. asperellum T36 NCAIM F 001434 and T. harzianum Td50b NCAIM F001412, both being deposited at the National Collection of Agricultural and Industrial Microorganisms (NCAIM), is highly biocompatible and demonstrated synergic plant biostimulant effects on nutraceuticals and vegetable crops.

Supplementary Materials: Supplementary materials can be found at http://www.mdpi.com/2076-2607/8/1/123/s1. Figure S1. The morphology of the mouse fibroblast NCTC L929 cells cultivated in media with treated plant extracts.

Author Contributions: Conceptualization, T.E.S. and F.O.; methodology F.O.; validation, A.O.O., M.G. and I.R.; formal analysis, C.M.P.; investigation, L.M.Ș., A.T., S.S., V.S.M., A.F.B.; resources, F.O.; data curation, D.C.-A.; writing—original draft preparation, T.E.S.; writing—review and editing, F.O. and D.C.-A.; visualization, F.O. and D.C.-A.; supervision, F.O.; project administration, F.O. All authors have read and agreed to the published version of the manuscript.

Funding: This work was supported by the Romanian Ministry of Research and Innovation, CCCDI- UEFISCDI, through following research projects: PN-III-P1-1.2-PCCDI-2017-0569 PRO-SPER, "Closing the bioeconomy value chains by manufacturing market-driven innovative bioproducts" (contract 10 PCCDI) and ERA.NET FACCE.SURPLUS DEBUT "Production of ferulic acid, 2,3 Butanediol and microbial plant biostimulants from lignocellulosic biomass by a two-step cascading process"(contract 43/2018), within PNCDI IIII. APC was paid from project ERA.NET FACCE.SURPLUS DEBUT.

Acknowledgments: The authors thank Geta Negru and Gelu Vasilescu for their support during field experiments.

Conflicts of Interest: The authors declare no conflict of interest.

\section{References}

1. Woo, S.L.; Ruocco, M.; Vinale, F.; Nigro, M.; Marra, R.; Lombardi, N.; Pascale, A.; Lanzuise, S.; Manganiello, G.; Lorito, M. Trichoderma-based products and their widespread use in agriculture. Open Mycol. J. 2014, 8, 71-126. [CrossRef]

2. Xue, A.G.; Guo, W.; Chen, Y.H.; Siddiqui, I.; Marchand, G.; Liu, J.H.; Ren, C.Z. Effect of seed treatment with novel strains of Trichoderma spp. on establishment and yield of spring wheat. Crop Prot. 2017, 96, 97-102. [CrossRef]

3. Fiorentino, N.; Ventorino, V.; Woo, S.L.; Pepe, O.; De Rosa, A.; Gioia, L.; Romano, I.; Lombardi, N.; Napolitano, M.; Colla, G.; et al. Trichoderma-Based Biostimulants Modulate Rhizosphere Microbial Populations and Improve N Uptake Efficiency, Yield, and Nutritional Quality of Leafy Vegetables. Front. Plant Sci. 2018, 9, 15. [CrossRef] [PubMed]

4. Kowalska, J. Effects of Trichoderma asperellum T1 on Botrytis cinerea pers.: Fr., growth and yield of organic strawberry. Acta Sci. Pol.-Hortorum Cultus 2011, 10, 107-114.

5. Kaewchai, S.; Soytong, K.; Hyde, K.D. Mycofungicides and fungal biofertilizers. Fungal Divers. 2009, 38, 25-50.

6. Vos, C.M.F.; De Cremer, K.; Cammue, B.P.A.; De Coninck, B. The toolbox of Trichoderma spp. in the biocontrol of Botrytis cinerea disease. Mol. Plant Pathol. 2015, 16, 400-412. [CrossRef]

7. López-Bucio, J.; Pelagio-Flores, R.; Herrera-Estrella, A. Trichoderma as biostimulant: Exploiting the multilevel properties of a plant beneficial fungus. Sci. Hortic. 2015, 196, 109-123. [CrossRef]

8. Chen, M.; Liu, Q.; Gao, S.-S.; Young, A.E.; Jacobsen, S.E.; Tang, Y. Genome mining and biosynthesis of a polyketide from a biofertilizer fungus that can facilitate reductive iron assimilation in plant. Proc. Natl. Acad. Sci. USA 2019, 116, 5499-5504. [CrossRef]

9. Verma, M.; Brar, S.K.; Tyagi, R.D.; Surampalli, R.Y.; Valero, J.R. Antagonistic fungi, Trichoderma spp.: Panoply of biological control. Biochem. Eng. J. 2007, 37, 1-20. [CrossRef] 
10. Harman, G.E.; Howell, C.R.; Viterbo, A.; Chet, I.; Lorito, M. Trichoderma species - Opportunistic, avirulent plant symbionts. Nat. Rev. Microbiol. 2004, 2, 43-56. [CrossRef]

11. Hermosa, R.; Viterbo, A.; Chet, I.; Monte, E. Plant-beneficial effects of Trichoderma and of its genes. Microbiology 2012, 158, 17-25. [CrossRef]

12. Hermosa, R.; Rubio, M.B.; Cardoza, R.E.; Nicolas, C.; Monte, E.; Gutierrez, S. The contribution of Trichoderma to balancing the costs of plant growth and defense. Int. Microbiol. 2013, 16, 69-80. [CrossRef]

13. Gaderer, R.; Lamdan, N.L.; Frischmann, A.; Sulyok, M.; Krska, R.; Horwitz, B.A.; Seidl-Seiboth, V. Sm2, a paralog of the Trichoderma cerato-platanin elicitor $\mathrm{Sm} 1$, is also highly important for plant protection conferred by the fungal-root interaction of Trichoderma with maize. BMC Microbiol. 2015, 15, 9. [CrossRef] [PubMed]

14. Gomes, E.V.; Costa, M.D.; de Paula, R.G.; de Azevedo, R.R.; da Silva, F.L.; Noronha, E.F.; Ulhoa, C.J.; Monteiro, V.N.; Cardoza, R.E.; Gutierrez, S.; et al. The Cerato-Platanin protein Epl-1 from Trichoderma harzianum is involved in mycoparasitism, plant resistance induction and self cell wall protection. Sci. Rep. 2015, 5, 13. [CrossRef] [PubMed]

15. Nawrocka, J.; Malolepsza, U. Diversity in plant systemic resistance induced by Trichoderma. Biol. Control 2013, 67, 149-156. [CrossRef]

16. Singh, B.N.; Dwivedi, P.; Sarma, B.K.; Singh, G.S.; Singh, H.B. Trichoderma asperellum T42 Reprograms Tobacco for Enhanced Nitrogen Utilization Efficiency and Plant Growth When Fed with N Nutrients. Front. Plant Sci. 2018, 9, 15. [CrossRef]

17. Pelagio-Flores, R.; Esparza-Reynoso, S.; Garnica-Vergara, A.; Lopez-Bucio, J.; Herrera-Estrella, A. Trichoderma-Induced Acidification Is an Early Trigger for Changes in Arabidopsis Root Growth and Determines Fungal Phytostimulation. Front. Plant Sci. 2017, 8, 13. [CrossRef]

18. Garnica-Vergara, A.; Barrera-Ortiz, S.; Munoz-Parra, E.; Raya-Gonzalez, J.; Mendez-Bravo, A.; Macias-Rodriguez, L.; Ruiz-Herrera, L.F.; Lopez-Bucio, J. The volatile 6-pentyl-2H-pyran-2-one from Trichoderma atroviride regulates Arabidopsis thaliana root morphogenesis via auxin signaling and ETHYLENE INSENSITIVE 2 functioning. New Phytol. 2016, 209, 1496-1512. [CrossRef]

19. Coppola, M.; Diretto, G.; Digilio, M.C.; Woo, S.L.; Giuliano, G.; Molisso, D.; Pennacchio, F.; Lorito, M.; Rao, R. Transcriptome and Metabolome Reprogramming in Tomato Plants by Trichoderma harzianum strain T22 Primes and Enhances Defense Responses Against Aphids. Front. Physiol. 2019, 10. [CrossRef]

20. Mona, S.A.; Hashem, A.; Abd_Allah, E.F.; Alqarawi, A.A.; Soliman, D.W.K.; Wirth, S.; Egamberdieva, D. Increased resistance of drought by Trichoderma harzianum fungal treatment correlates with increased secondary metabolites and proline content. J. Integr. Agric. 2017, 16, 1751-1757. [CrossRef]

21. Sánchez-Montesinos, B.; Diánez, F.; Moreno-Gavira, A.; Gea, F.J.; Santos, M. Plant Growth Promotion and Biocontrol of Pythium ultimum by Saline Tolerant Trichoderma Isolates under Salinity Stress. Int. J. Environ. Res. Public Health 2019, 16, 2053. [CrossRef] [PubMed]

22. Ghorbanpour, A.; Salimi, A.; Ghanbary, M.A.T.; Pirdashti, H.; Dehestani, A. The effect of Trichoderma harzianum in mitigating low temperature stress in tomato (Solanum lycopersicum L.) plants. Sci. Hortic. 2018, 230, 134-141. [CrossRef]

23. Tripathi, P.; Singh, P.C.; Mishra, A.; Chauhan, P.S.; Dwivedi, S.; Bais, R.T.; Tripathi, R.D. Trichoderma: A potential bioremediator for environmental clean up. Clean Technol. Environ. Policy 2013, 15, 541-550. [CrossRef]

24. Harman, G.E.; Doni, F.; Khadka, R.B.; Uphoff, N. Endophytic strains of Trichoderma increase plants' photosynthetic capability. J. Appl. Microbiol. 2019. [CrossRef] [PubMed]

25. Garcia-Lopez, A.; Recena, R.; Aviles, M.; Delgado, A. Effect of Bacillus subtilis QST713 and Trichoderma asperellum T34 on P uptake by wheat and how it is modulated by soil properties. J. Soils Sediments 2018, 18, 727-738. [CrossRef]

26. Li, R.X.; Cai, F.; Pang, G.; Shen, Q.R.; Li, R.; Chen, W. Solubilisation of Phosphate and Micronutrients by Trichoderma harzianum and Its Relationship with the Promotion of Tomato Plant Growth. PLoS ONE 2015, 10, 16. [CrossRef]

27. de Santiago, A.; Quintero, J.M.; Aviles, M.; Delgado, A. Effect of Trichoderma asperellum strain T34 on iron, copper, manganese, and zinc uptake by wheat grown on a calcareous medium. Plant Soil 2011, 342, 97-104. [CrossRef]

28. Martinez-Medina, A.; Van Wees, S.C.M.; Pieterse, C.M.J. Airborne signals from Trichoderma fungi stimulate iron uptake responses in roots resulting in priming of jasmonic acid-dependent defences in shoots of Arabidopsis thaliana and Solanum lycopersicum. Plant Cell Environ. 2017, 40, 2691-2705. [CrossRef] 
29. Akter, Z.; Neumann, G.; Romheld, V. Effects of biofertilizers on $\mathrm{mn}$ and zn acquisition and growth of higher plants: A rhizobox experiment. J. Plant Nutr. 2015, 38, 596-608. [CrossRef]

30. Goicoechea, N.; Antolin, M.C. Increased nutritional value in food crops. Microb. Biotechnol. 2017, 10, 1004-1007. [CrossRef]

31. Zhao, J.; Davis, L.C.; Verpoorte, R. Elicitor signal transduction leading to production of plant secondary metabolites. Biotechnol. Adv. 2005, 23, 283-333. [CrossRef] [PubMed]

32. Gertsch, J. The metabolic plant feedback hypothesis: How plant secondary metabolites nonspecifically impact human health. Planta Med. 2016, 82, 920-929. [CrossRef]

33. Gupta, R.; Singh, A.; Gupta, M.M.; Pandey, R. Cumulative role of bioinoculants on growth, antioxidant potential and artemisinin content in Artemisia annua L. under organic field conditions. World J. Microbiol. Biotechnol. 2016, 32, 10. [CrossRef] [PubMed]

34. Singh, S.P.; Singh, H.B.; Singh, D.K. Effect of Trichoderma harzianum on Mineral Component and Antioxidant Activity of Tomato Fruits. Vegetos 2013, 26, 237-244. [CrossRef]

35. Pascale, A.; Vinale, F.; Manganiello, G.; Nigro, M.; Lanzuise, S.; Ruocco, M.; Marra, R.; Lombardi, N.; Woo, S.L.; Lorito, M. Trichoderma and its secondary metabolites improve yield and quality of grapes. Crop Prot. 2017, 92, 176-181. [CrossRef]

36. Rouphael, Y.; Colla, G.; Graziani, G.; Ritieni, A.; Cardarelli, M.; De Pascale, S. Phenolic composition, antioxidant activity and mineral profile in two seed-propagated artichoke cultivars as affected by microbial inoculants and planting time. Food Chem. 2017, 234, 10-19. [CrossRef]

37. Ortega-Garcia, J.G.; Montes-Belmont, R.; Rodriguez-Monroy, M.; Ramirez-Trujillo, J.A.; Suarez-Rodriguez, R.; Sepulveda-Jimenez, G. Effect of Trichoderma asperellum applications and mineral fertilization on growth promotion and the content of phenolic compounds and flavonoids in onions. Sci. Hortic. 2015, 195, 8-16. [CrossRef]

38. Nawrocka, J.; Szczech, M.; Malolepsza, U. Trichoderma atroviride Enhances Phenolic Synthesis and Cucumber Protection against Rhizoctonia solani. Plant Prot. Sci. 2018, 54, 17-23. [CrossRef]

39. Zeraik, M.L.; Pereira, C.A.M.; Zuin, V.G.; Yariwake, J.H. Passion fruit: A functional food? Rev. Bras. Farmacogn.-Braz. J. Pharmacogn. 2010, 20, 459-471. [CrossRef]

40. Miyasaka, L.S.; Atallah, Á.N.; Soares, B. Passiflora for anxiety disorder. Cochrane Database Syst. Rev. 2007. [CrossRef]

41. Deng, J.; Zhou, Y.J.; Bai, M.M.; Li, H.W.; Li, L. Anxiolytic and sedative activities of Passiflora edulis f. flavicarpa. J. Ethnopharmacol. 2010, 128, 148-153. [CrossRef] [PubMed]

42. Guerrero, F.A.; Medina, G.M. Effect of a medicinal plant (Passiflora incarnata) on sleep. Sleep Sci. 2017, 10, 96-100. [CrossRef] [PubMed]

43. Anzoise, M.L.; Marrassini, C.; Bach, H.; Gorzalczany, S. Beneficial properties of Passiflora caerulea on experimental colitis. J. Ethnopharmacol. 2016, 194, 137-145. [CrossRef] [PubMed]

44. Miroddi, M.; Calapai, G.; Navarra, M.; Minciullo, P.L.; Gangemi, S. Passiflora incarnata L.: Ethnopharmacology, clinical application, safety and evaluation of clinical trials. J. Ethnopharmacol. 2013, 150, 791-804. [CrossRef] [PubMed]

45. Sudasinghe, H.P.; Peiris, D.C. Hypoglycemic and hypolipidemic activity of aqueous leaf extract of Passiflora suberosa L. PeerJ 2018, 6, e4389. [CrossRef] [PubMed]

46. Konta, E.M.; Almeida, M.R.; do Amaral, C.L.; Darin, J.D.C.; de Rosso, V.V.; Mercadante, A.Z.; Antunes, L.M.G.; Bianchi, M.L.P. Evaluation of the Antihypertensive Properties of Yellow Passion Fruit Pulp (Passiflora edulis Sims f. flavicarpa Deg.) in Spontaneously Hypertensive Rats. Phytother. Res. 2014, 28, 28-32. [CrossRef]

47. Schunck, R.V.A.; Macedo, I.C.; Laste, G.; de Souza, A.; Valle, M.T.C.; Salomon, J.L.O.; Nunes, E.A.; Campos, A.C.W.; Gnoatto, S.C.B.; Bergold, A.M.; et al. Standardized Passiflora incarnata L. Extract Reverts the Analgesia Induced by Alcohol Withdrawal in Rats. Phytother. Res. 2017, 31, 1199-1208. [CrossRef]

48. Breivogel, C.; Jamerson, B. Passion flower extract antagonizes the expression of nicotine locomotor sensitization in rats. Pharm. Biol. 2012, 50, 1310-1316. [CrossRef]

49. Gadioli, I.L.; da Cunha, M.D.B.; de Carvalho, M.V.O.; Costa, A.M.; Pineli, L.D.D. A systematic review on phenolic compounds in Passiflora plants: Exploring biodiversity for food, nutrition, and popular medicine. Crit. Rev. Food Sci. Nutr. 2018, 58, 785-807. [CrossRef]

50. Argentieri, M.P.; Levi, M.; Guzzo, F.; Avato, P. Phytochemical analysis of Passiflora loefgrenii Vitta, a rich source of luteolin-derived flavonoids with antioxidant properties. J. Pharm. Pharmacol. 2015, 67, 1603-1612. [CrossRef] 
51. da Silva, J.K.; Cazarin, C.B.B.; Colomeu, T.C.; Batista, Â.G.; Meletti, L.M.M.; Paschoal, J.A.R.; Bogusz Júnior, S.; Furlan, M.F.; Reyes, F.G.R.; Augusto, F.; et al. Antioxidant activity of aqueous extract of passion fruit (Passiflora edulis) leaves: In vitro and in vivo study. Food Res. Int. 2013, 53, 882-890. [CrossRef]

52. Bendini, A.; Cerretani, L.; Pizzolante, L.; Toschi, T.G.; Guzzo, F.; Ceoldo, S.; Marconi, A.M.; Andreetta, F.; Levi, M. Phenol content related to antioxidant and antimicrobial activities of Passiflora spp. extracts. Eur. Food Res. Technol. 2006, 223, 102-109. [CrossRef]

53. Lugato, D.; Simo, M.J.; Garcia, R.; Mansur, E.; Pacheco, G. Determination of antioxidant activity and phenolic content of extracts from in vivo plants and in vitro materials of Passiflora alata Curtis. Plant Cell Tissue Organ Cult. 2014, 118, 339-346. [CrossRef]

54. Nguyen, T.Y.; To, D.C.; Tran, M.H.; Lee, J.S.; Lee, J.H.; Kim, J.A.; Woo, M.H.; Min, B.S. Anti-inflammatory Flavonoids Isolated from Passiflora foetida. Nat. Prod. Commun. 2015, 10, 929-931. [CrossRef] [PubMed]

55. Saravanan, S.; Arunachalam, K.; Parimelazhagan, T. Antioxidant, analgesic, anti-inflammatory and antipyretic effects of polyphenols from Passiflora subpeltata leaves - A promising species of Passiflora. Ind. Crop. Prod. 2014, 54, 272-280. [CrossRef]

56. Sasikala, V.; Saravanan, S.; Parimelazhagan, T. Analgesic and anti-inflammatory activities of Passiflora foetida L. Asian Pac. J. Trop. Med. 2011, 4, 600-603. [CrossRef]

57. Barbosa, M.A.G.; Rehn, K.G.; Menezes, M.; Mariano, R. Antagonism of Trichoderma species on Cladosporium herbarum and their enzimatic characterization. Braz. J. Microbiol. 2001, 32, 98-104. [CrossRef]

58. Fischer, I.H.; de Almeida, A.M.; Fileti, M.D.; Bertani, R.M.D.; de Arruda, M.C.; Bueno, C.J. Evaluation of Passifloraceas, fungicides and Trichoderma for passion fruit collar rot handling, caused by Nectria haematococca. Rev. Bras. De Frutic. 2010, 32, 709-717. [CrossRef]

59. dos Santos, H.A.; Mello, S.C.M.; Peixoto, J.R. Association of isolates of Trichoderma spp. and indole-3-butyric acid (iba) in promoting root and growth of Passion. Biosci. J. 2010, 26, 966-972.

60. Hassani, M.A.; Duran, P.; Hacquard, S. Microbial interactions within the plant holobiont. Microbiome 2018, 6, 17. [CrossRef]

61. Yuan, M.; Huang, Y.; Jia, Z.; Ge, W.; Zhang, L.; Zhao, Q.; Song, S.; Huang, Y. Whole RNA-sequencing and gene expression analysis of Trichoderma harzianum Tr-92 under chlamydospore-producing condition. Genes Genom. 2019, 41, 689-699. [CrossRef] [PubMed]

62. Răut, I.; Badea-Doni, M.; Calin, M.; Oancea, F.; Vasilescu, G.; Sesan, T.E.; Jecu, L. Effect of volatile and non-volatile metabolites from Trichoderma spp. Against important phytopathogens. Rev Chim-Buchar. 2014, $65,1285-1288$.

63. Oancea, F.; Mara, G.; Sesan, T.; Máthé, I.; Raut, J.; Ábrahám, B.; Lányi, S. Strain of Trichoderma harzianum and Controlled Release Composition Which Contains Said Strain. Patent RO 128889 B1, 30 June 2017.

64. Răut, I.; Calin, M.; Vasilescu, G.; Doni, M.; Sesan, T.; Jecu, L. Effect of non volatile compounds of Trichoderma spp. against Fusarium graminearum, Rhizoctonia solani and Pythium ultimum. Sci. Bull. Ser. F. Biotechnol. 2014, 18, 178-181.

65. Răut, I.; Sesan, T.E.; Macias, R.; Doni, M.B.; Oancea, F.; Calin, M.; Arsene, M.L.; Vasilescu, G.; Jecu, L. Study on the effectiveness of antagonistic Trichoderma spp. on the growth of some vegetables under laboratory and greenhouse conditions. Rev. Chim-Buchar. 2016, 67, 1504-1507.

66. Răut, I.; Oancea, F.; Sesan, T.E.; Jecu, L.; Arsene, M.L.; Doni, M.B.; Vasilescu, G. Trichoderma asperellum Td36-Versatile strain for treatment of high residue agricultural systems and nutraceutical crops. J. Biotechnol. 2015, 208, S62. [CrossRef]

67. Oancea, F.; Raut, I.; Șesan, T.E.; Cornea, P.C.; Badea-Doni, M.; Popescu, M.; Jecu, M.L. Hydro-gelified and film forming formulation of microbial plant biostimulants for crop residues treatment on conservation agriculture systems. Studia Univ. Vasile Goldis Ser. Stiintele Vietii (Life Sci. Ser.) 2016, 26, 251-260.

68. ZamfiropoL-Cristea, V.; Răut, I.; Șeșan, T.E.; Trică, B.; Oancea, F. Surface response optimization of submerged biomass production for a plant biostimulant trichoderma strain. Sci. Bull. Ser. F. Biotechnol. 2017, 21, 56-65.

69. Oancea, F.; Raut, I.; Şesan, T.E.; Cornea, P.C. Dry flowable formulation of biostimulants Trichoderma strains. Agric. Agric. Sci. Procedia 2016, 10, 494-502. [CrossRef]

70. Aberkane, A.; Cuenca-Estrella, M.; Gomez-Lopez, A.; Petrikkou, E.; Mellado, E.; Monzon, A.; Rodriguez-Tudela, J. Comparative evaluation of two different methods of inoculum preparation for antifungal susceptibility testing of filamentous fungi. J. Antimicrob. Chemother. 2002, 50, 719-722. [CrossRef] 
71. Rouphael, Y.; Giordano, M.; Cardarelli, M.; Cozzolino, E.; Mori, M.; Kyriacou, M.C.; Bonini, P.; Colla, G. Plantand Seaweed-Based Extracts Increase Yield but Differentially Modulate Nutritional Quality of Greenhouse Spinach through Biostimulant Action. Agronomy 2018, 8, 126. [CrossRef]

72. Sârbu, A.; Paraschiv, M.A.; Oancea, F.; Şesan, T.E. Passiflora caerulea L. Treated with Trichoderma plant biostimulants consortium. Morpho-anatomical considerations. J. Plant Dev. 2018, 25, 2-14.

73. Sesan, T.E.; Sârbu, A.; Smarandache, D.; Oancea, F.; Oancea, A.; Savin, S.; Toma, A.; Stefan, L.; Negru, G.; Bira, A.F. Botanical and Phytochemical Approach on Passiflora Spp.-New Nutraceutical Crop in Romania. J. Plant Dev. 2016, 23, 97-127.

74. Plotze, R.d.O.; Falvo, M.; Pádua, J.G.; Bernacci, L.C.; Vieira, M.L.C.; Oliveira, G.C.X.; Bruno, O.M. Leaf shape analysis using the multiscale Minkowski fractal dimension, a new morphometric method: A study with Passiflora (Passifloraceae). Can. J. Bot. 2005, 83, 287-301. [CrossRef]

75. Morgado, M.A.D.O.; Bruckner, C.H.; Rosado, L.D.S.; Assunção, W.; dos Santos, C.E.M. Estimação da área foliar por método não destrutivo, utilizando medidas lineares das folhas de espécies de Passiflora. Rev. Ceres 2015, 60, 662-667. [CrossRef]

76. Zechmann, B. Ultrastructure of plastids serves as reliable abiotic and biotic stress marker. PLoS ONE 2019, 14, e0214811. [CrossRef]

77. Huang, D.; Ou, B.; Prior, R.L. The chemistry behind antioxidant capacity assays. J. Agric. Food Chem. 2005, 53, 1841-1856. [CrossRef]

78. Craciunescu, O.; Constantin, D.; Gaspar, A.; Toma, L.; Utoiu, E.; Moldovan, L. Evaluation of antioxidant and cytoprotective activities of Arnica montana L. and Artemisia absinthium L. ethanolic extracts. Chem. Cent. J. 2012, 6, 97. [CrossRef]

79. Chang, C.-C.; Yang, M.-H.; Wen, H.-M.; Chern, J.-C. Estimation of total flavonoid content in propolis by two complementary colorimetric methods. J. Food Drug Anal. 2002, 10, 178-182.

80. Repetto, G.; Del Peso, A.; Zurita, J.L. Neutral red uptake assay for the estimation of cell viability/cytotoxicity. Nat. Protoc. 2008, 3, 1125. [CrossRef] [PubMed]

81. Contreras-Cornejo, H.A.; Macias-Rodriguez, L.; Vergara, A.G.; Lopez-Bucio, J. Trichoderma Modulates Stomatal Aperture and Leaf Transpiration Through an Abscisic Acid-Dependent Mechanism in Arabidopsis. J. Plant Growth Regul. 2015, 34, 425-432. [CrossRef]

82. Fiorini, L.; Guglielminetti, L.; Mariotti, L.; Curadi, M.; Picciarelli, P.; Scartazza, A.; Sarrocco, S.; Vannacci, G. Trichoderma harzianum T6776 modulates a complex metabolic network to stimulate tomato cv. Micro-Tom growth. Plant Soil 2016, 400, 351-366. [CrossRef]

83. El-Bakry, H.A.; El-Sherif, G.; Rostom, R.M. Therapeutic dose of green tea extract provokes liver damage and exacerbates paracetamol-induced hepatotoxicity in rats through oxidative stress and caspase 3-dependent apoptosis. Biomed. Pharmacother. 2017, 96, 798-811. [CrossRef] [PubMed]

84. Kocyigit, A.; Selek, S. Exogenous Antioxidants are Double-edged Swords. Bezmialem Sci. 2016, 4, 70-75. [CrossRef]

85. Jain, A.K.; Singh, D.; Dubey, K.; Maurya, R.; Mittal, S.; Pandey, A.K. Models and methods for in vitro toxicity. In In Vitro Toxicology; Dhawan, A., Kwon, S., Eds.; Academic Press: Cambridge, MA, USA, 2018; pp. $45-65$. [CrossRef]

86. Krishna, G.; Gopalakrishnan, G. Alternative in vitro models for safety and toxicity evaluation of nutraceuticals. In Nutraceuticals; Gupta, R.C., Ed.; Academic Press: Cambridge, MA, USA, 2016; pp. 355-385. [CrossRef]

87. Uțoiu, E.; Matei, F.; Toma, A.; Diguță, C.F.; Ștefan, L.M.; Mănoiu, S.; Vrăjmașu, V.V.; Moraru, I.; Oancea, A.; Israel-Roming, F.; et al. Bee Collected Pollen with Enhanced Health Benefits, Produced by Fermentation with a Kombucha Consortium. Nutrients 2018, 10, 1365. [CrossRef] [PubMed]

88. Vajrabhaya, L.-O; Korsuwannawong, S. Cytotoxicity evaluation of a thai herb using tetrazolium (MTT) and sulforhodamine b (SRB) assays. J. Anal. Sci. Technol. 2018, 9, 15. [CrossRef]

89. Andrews, J.H. Biological control in the phyllosphere. Annu. Rev. Phytopathol. 1992, 30, 603-635. [CrossRef] [PubMed]

90. Elad, Y.; Kirshner, B. Survival in the phylloplane of an introduced biocontrol agent (Trichoderma harzianum) and populations of the plant pathogen Botrytis cinerea as modified by abiotic conditions. Phytoparasitica 1993, 21, 303. [CrossRef]

91. Peteu, S.F.; Oancea, F.; Sicuia, O.A.; Constantinescu, F.; Dinu, S. Responsive polymers for crop protection. Polymers 2010, 2, 229-251. [CrossRef] 
92. Nix-Stohr, S.; Moshe, R.; Dighton, J. Effects of Propagule Density and Survival Strategies on Establishment and Growth: Further Investigations in the Phylloplane Fungal Model System. Microb. Ecol. 2008, 55, 38-44. [CrossRef]

93. Li, Y.-Q.; Song, K.; Li, Y.-C.; Chen, J. Statistical culture-based strategies to enhance chlamydospore production by Trichoderma harzianum SH2303 in liquid fermentation. J. Zhejiang Univ. Sci. B 2016, 17, 619-627. [CrossRef]

94. van der Burgh, A.M.; Joosten, M.H.A.J. Plant Immunity: Thinking Outside and Inside the Box. Trends Plant Sci. 2019, 24, 587-601. [CrossRef] [PubMed]

95. Ramírez-Valdespino, C.A.; Casas-Flores, S.; Olmedo-Monfil, V. Trichoderma as a Model to Study Effector-Like Molecules. Front. Microbiol. 2019, 10. [CrossRef]

96. de Torres Zabala, M.; Littlejohn, G.; Jayaraman, S.; Studholme, D.; Bailey, T.; Lawson, T.; Tillich, M.; Licht, D.; Bölter, B.; Delfino, L.; et al. Chloroplasts play a central role in plant defence and are targeted by pathogen effectors. Nat. Plants 2015, 1, 15074. [CrossRef]

97. Stael, S.; Kmiecik, P.; Willems, P.; Van Der Kelen, K.; Coll, N.S.; Teige, M.; Van Breusegem, F. Plant innate immunity - sunny side up? Trends Plant Sci. 2015, 20, 3-11. [CrossRef]

98. Serrano, I.; Audran, C.; Rivas, S. Chloroplasts at work during plant innate immunity. J. Exp. Bot. 2016, 67, 3845-3854. [CrossRef]

99. Peng, K.C.; Lin, C.C.; Liao, C.F.; Yu, H.C.; Lo, C.T.; Yang, H.H.; Lin, K.C. L-amino Acid Oxidase Secreted by Trichoderma Elicits Systemic Resistance by Transporting to Chloroplasts of Host Cells and Targeting Chlorophyll a/b Binding Proteins. Mol. Plant-Microbe Interact. 2019, 32, 111.

100. du Jardin, P. Plant biostimulants: Definition, concept, main categories and regulation. Sci. Hortic. 2015, 196, 3-14. [CrossRef]

101. Bulgari, R.; Franzoni, G.; Ferrante, A. Biostimulants Application in Horticultural Crops under Abiotic Stress Conditions. Agronomy 2019, 9, 306. [CrossRef]

102. Abreu, P.P.; Souza, M.M.; de Almeida, A.-A.F.; Santos, E.A.; Freitas, J.C.d.O.; Figueiredo, A.L. Photosynthetic responses of ornamental passion flower hybrids to varying light intensities. Acta Physiol. Plant. 2014, 36, 1993-2004. [CrossRef]

103. Szymanska, R.; Slesak, I.; Orzechowska, A.; Kruk, J. Physiological and biochemical responses to high light and temperature stress in plants. Environ. Exp. Bot. 2017, 139, 165-177. [CrossRef]

104. Chen, S.C.; Ren, J.J.; Zhao, H.J.; Wang, X.L.; Wang, T.H.; Jin, S.D.; Wang, Z.H.; Li, C.Y.; Liu, A.R.; Lin, X.M.; et al. Trichoderma harzianum Improves Defense Against Fusarium oxysporum by Regulating ROS and RNS Metabolism, Redox Balance, and Energy Flow in Cucumber Roots. Phytopathology 2019, 109, 972-982. [CrossRef] [PubMed]

105. Herrera-Téllez, V.I.; Cruz-Olmedo, A.K.; Plasencia, J.; Gavilanes-Ruíz, M.; Arce-Cervantes, O.; Hernández-León, S.; Saucedo-García, M. The Protective Effect of Trichoderma asperellum on Tomato Plants against Fusarium oxysporum and Botrytis cinerea Diseases Involves Inhibition of Reactive Oxygen Species Production. Int. J. Mol. Sci. 2019, 20, 2007. [CrossRef] [PubMed]

106. Fu, J.; Liu, Z.; Li, Z.; Wang, Y.; Yang, K. Alleviation of the effects of saline-alkaline stress on maize seedlings by regulation of active oxygen metabolism by Trichoderma asperellum. PLoS ONE 2017, 12, e0179617. [CrossRef] [PubMed]

107. Souza, P.U.; Lima, L.K.S.; Soares, T.L.; Jesus, O.N.d.; Coelho Filho, M.A.; Girardi, E.A. Biometric, physiological and anatomical responses of Passiflora spp. to controlled water deficit. Sci. Hortic. 2018, 229, 77-90. [CrossRef]

108. Drake, P.L.; de Boer, H.J.; Schymanski, S.J.; Veneklaas, E.J. Two sides to every leaf: Water and CO2 transport in hypostomatous and amphistomatous leaves. New Phytol. 2019, 222, 1179-1187. [CrossRef] [PubMed]

109. Tosens, T.; Laanisto, L. Mesophyll conductance and accurate photosynthetic carbon gain calculations. J. Exp. Bot. 2018, 69, 5315-5318. [CrossRef]

110. Romanatti, P.V.; Rocha, G.A.; Veroneze Júnior, V.; Santos Filho, P.R.; de Souza, T.C.; Pereira, F.J.; Polo, M. Limitation to photosynthesis in leaves of eggplant under UVB according to anatomical changes and alterations on the antioxidant system. Sci. Hortic. 2019, 249, 449-454. [CrossRef]

111. Zou, M.; Yuan, L.; Zhu, S.; Liu, S.; Ge, J.; Wang, C. Effects of heat stress on photosynthetic characteristics and chloroplast ultrastructure of a heat-sensitive and heat-tolerant cultivar of wucai (Brassica campestris L.). Acta Physiol. Plant. 2016, 39, 30. [CrossRef] 
112. Latif, H.H.; Mohamed, H.I. Exogenous applications of moringa leaf extract effect on retrotransposon, ultrastructural and biochemical contents of common bean plants under environmental stresses. S. Afr. J. Bot. 2016, 106, 221-231. [CrossRef]

113. Guo, L.; Chen, A.; He, N.; Yang, D.; Liu, M. Exogenous silicon alleviates cadmium toxicity in rice seedlings in relation to Cd distribution and ultrastructure changes. J. Soils Sediments 2018, 18, 1691-1700. [CrossRef]

114. Sharma, A.; Shahzad, B.; Rehman, A.; Bhardwaj, R.; Landi, M.; Zheng, B.S. Response of Phenylpropanoid Pathway and the Role of Polyphenols in Plants under Abiotic Stress. Molecules 2019, 24, 2452. [CrossRef] [PubMed]

115. Singh, U.B.; Malviya, D.; Singh, S.; Kumar, M.; Sahu, P.K.; Singh, H.V.; Kumar, S.; Roy, M.; Imran, M.; Rai, J.P.; et al. Trichoderma harzianum- and Methyl Jasmonate-Induced Resistance to Bipolaris sorokiniana Through Enhanced Phenylpropanoid Activities in Bread Wheat (Triticum aestivum L.). Front. Microbiol. 2019, 10, 19. [CrossRef] [PubMed]

116. Vogt, T. Phenylpropanoid Biosynthesis. Mol. Plant 2010, 3, 2-20. [CrossRef] [PubMed]

117. Carrington, Y.; Guo, J.; Le, C.H.; Fillo, A.; Kwon, J.; Tran, L.T.; Ehlting, J. Evolution of a secondary metabolic pathway from primary metabolism: Shikimate and quinate biosynthesis in plants. Plant J. 2018, 95, 823-833. [CrossRef]

118. de Oliveira, D.M.; Finger-Teixeira, A.; Rodrigues Mota, T.; Salvador, V.H.; Moreira-Vilar, F.C.; Correa Molinari, H.B.; Craig Mitchell, R.A.; Marchiosi, R.; Ferrarese-Filho, O.; Dantas dos Santos, W. Ferulic acid: A key component in grass lignocellulose recalcitrance to hydrolysis. Plant Biotechnol. J. 2015, 13, 1224-1232. [CrossRef]

119. Shukla, N.; Awasthi, R.P.; Rawat, L.; Kumar, J. Seed biopriming with drought tolerant isolates of Trichoderma harzianum promote growth and drought tolerance in Triticum aestivum. Ann. Appl. Biol. 2015, 166, 171-182. [CrossRef]

120. Czarnocka, W.; Karpiński, S. Friend or foe? Reactive oxygen species production, scavenging and signaling in plant response to environmental stresses. Free Radic. Biol. Med. 2018, 122, 4-20. [CrossRef]

121. Ehonen, S.; Yarmolinsky, D.; Kollist, H.; Kangasjärvi, J. Reactive Oxygen Species, Photosynthesis, and Environment in the Regulation of Stomata. Antioxid. Redox Signal. 2018, 30, 1220-1237. [CrossRef] [PubMed] 